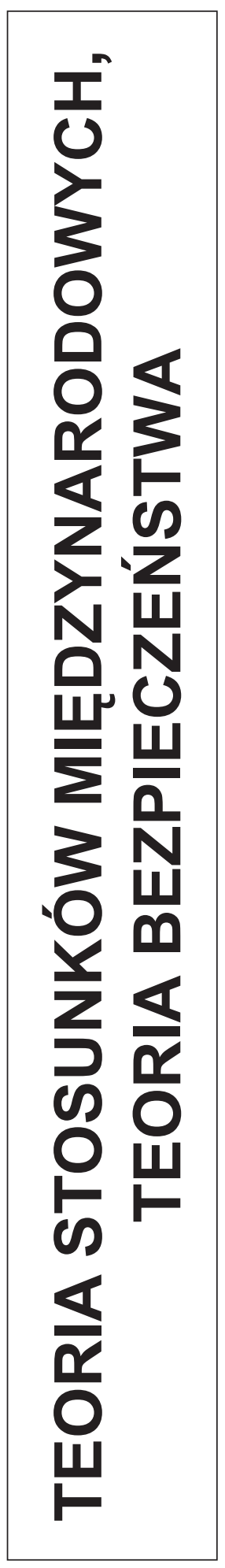





\section{Andrzej GAŁGANEK}

Uniwersytet im. Adama Mickiewicza w Poznaniu

\section{TEORIA STOSUNKÓW MIEDZYNARODOWYCH A FILOZOFIA NAUKI}

Przedmiotem artykułu są problemy związane z pytaniami fundacyjnymi (,,wyższego rzędu") w teorii stosunków międzynarodowych (dalej: TSM). Zadać je musi każda teoria społeczna zanim spróbuje odpowiedzieć na pytania dotyczące jej konkretnej dziedziny, czyli pytania ,„pierwszego rzędu”. TSM zatem również musi się zająć podstawami badań społecznych: naturą podmiotu sprawczego i jego stosunkiem do całości (struktur) społecznych, rolą idei i czynników materialnych w życiu społecznym, właściwym sposobem wyjaśniania i kryteriami, według których można o tym rozstrzygać itd. (Wendt, 2008: 14). Zasadniczo odpowiedzi na te pytania udziela filozofia nauki. Badacze stosunków międzynarodowych muszą jednak sformułować własne odpowiedzi, ponieważ ,nie mogą zajmować się swoją dziedziną, nie przyjmując mocnych przesłanek co do rodzaju spraw czy zjawisk, jakie występują w życiu międzynarodowym, tego, jak są one powiązane ze sobą oraz jak można je poznać. Założenia takie są szczególnie istotne, ponieważ nikt nie może 'zobaczyć' państwa czy systemu międzynarodowego. Polityka międzynarodowa nie jest dostępna naszym zmysłom bezpośrednio, a teorie polityki międzynarodowej są często kwestionowane na poziomie ontologii i epistemologii, to jest na poziomie tego co teoretyk "widzi"' (ibidem: 14). Można wprawdzie oczekiwać, że wraz z rozwojem dyscypliny prowadzone w jej ramach badania empiryczne przesądzą o tym, która teoria jest najlepsza, jednak badania „nieobserwowalnego" przedmiotu muszą być poprzedzone przyjętymi założeniami teoretycznymi. Taki wymóg narzuca nieusuwalny dystans między teorią a rzeczywistością.

Podstawowym celem artykułu jest analiza odpowiedzi, jakich badacze stosunków międzynarodowych udzielali na pytania „wyższego rzędu”. W szczególności zaś rozstrzygnięcie, czy udawanie się do filozofii nauki po radę, jakich odpowiedzi należy udzielić, gwarantuje powodzenie? Jeśli natomiast odpowiedzi filozofów nauki nie będą satysfakcjonujące, warto przedstawić alternatywne sposoby postępowania.

Etapom realizacji wymienionych celów odpowiadają trzy kolejne części artykułu. W części pierwszej przedstawiono odpowiedzi na pytania „wyższego rzędu” udzielane w TSM. Koncentrując się na trzeciej i czwartej debacie, przywołano skrótowo ich zawartość i istotę. Część druga zawiera odpowiedzi, jakich na pytania „wyższego rzędu" udzielają filozofowie nauki. W części trzeciej uznając, że odpowiedzi filozofów nauki nie są rozstrzygające, wysunięto propozycje alternatywnych sposobów postępowania. 


\section{DEBATY PARADYGMATYCZNE W NAUCE O STOSUNKACH MIĘDZYNARODOWYCH}

Opis stanu nauki o stosunkach międzynarodowych (dalej: NSM) często oscyluje między diagnozą o kłopotliwej teraźniejszości a wizją lepszej przyszłości, którą można osiagnąć drogą dialogu, pluralizmu i syntezy. Wskazanie najważniejszych przyczyn wzrastającej frustracji związanej z ,tym raczej anarchicznym polem” okazuje się jednak trudne (Hellman, 2003: 123) ${ }^{1}$. Kłopoty w komunikacji między badaczami rozpoczynają się już od różnic na najbardziej ogólnym poziomie rozumienia czym jest sama „nauka”.

W podręcznikach do NSM przedstawiane są zwykle dwie podstawowe wersje jej historii. Pierwsza, ukazuje chronologiczny rozwój dyscypliny, czyli następowanie po sobie dominujących perspektyw teoretycznych. Panujący w okresie międzywojennym idealizm został po drugiej wojnie światowej zastapiony przez realizm polityczny. Później dyscyplina przeszła w stadium interregnum, w którym rywalizowało ze sobą wiele podejść, przy czym szczególne oczekiwania wiązano z teoriami opatrywanymi etykietką behawioryzmu. Lata osiemdziesiąte XX w. zdominowała debata między neorealizmem a neoliberalizmem, która doprowadziła do niepewnego konsensu w głównym nurcie w ostatniej dekadzie stulecia. Równocześnie jednak ukształtowało się opozycyjne wobec tego nurtu podejście reflektywistyczne, obejmujące wiele różnych propozycji teoretycznych.

Wersja druga przedstawia historię dyscypliny jako serię ,wielkich debat” między konkurującymi perspektywami teoretycznymi: między idealizmem a realizmem w latach trzydziestych XX w., między tradycjonalizmem (idealizm i realizm) a behawioryzmem w latach sześćdziesiątych, między podejściem państwocentrycznym a transnacjonalistycznym w latach siedemdziesiątych, między trzema rywalizującymi paradygmatami (neorealizmem, neoliberalizmem i neomarksizmem) w tzw. ,międzyparadygmatycznej debacie" lat osiemdziesiątych oraz między neoneosyntezą (zwaną także racjonalizmem) a zestawem podejść alternatywnych (zwanych reflektywizmem), poczynając od ostatniej dekady stulecia (Smith, 2000: 376).

Niektórzy badacze uważaja, że problem z obu popularnymi wersjami tej dyscyplinarnej historii polega na tym, że obie mówią nieprawdę - przede wszystkim w kwestii otwartości i pluralizmu NSM oraz jej progresywności (Smith, 1995: 1-37). Obecny teoretyczny obraz dyscypliny znajduje, według Steve'a Smitha, wyraz w podziale na teorie należące do głównego nurtu: neorealizm i neoliberalizm oraz zyskujący na znaczeniu konstruktywizm, obejmowane określeniem racjonalizm (lub „teorie wyjaśniające") oraz teorie połączone jedynie swoją opozycyjnością do racjonalistycznego głównego nurtu, opatrywane terminem reflektywizm (lub „teorie konstytutywne”): teo-

1 Socjologowie także toczą podobne debaty metateoretyczne. Diagnozując kryzys swojej dyscypliny stawiają pytania o jej podstawowe cele, twardy rdzeń i tożsamość. Stan socjologii określają często jako „pluralistyczną konfuzję”, pogłębianą przez przekonanie o spadku zapotrzebowania na wiedzę socjologiczną. T. Brante podkreśla jednak, że socjologia nie znajduje się obecnie w szczególnie ostrym kryzysie, a jej sytuacja jest w przybliżeniu podobna do tej sprzed 10, 20, i 30 lat. Do kwestii tej wrócimy w ostatniej części artykułu. Zob. Branthe, 2001: 167, 188. 
ria krytyczna, postmodernizm, teoria feministyczna, teoria postkolonialna, teoria normatywna, studia nad pokojem, podejścia antropologiczne i socjologia historyczna.

Zgodnie z zapowiedzią, skupimy się na drugiej wersji historii dyscypliny. Przedstawimy skrótowo istotę poszczególnych debat (tabela 1), a następnie skomentujemy spory i rozstrzygnięcia dotyczące pytań „wyższego rzędu” oraz związane z nimi możliwości lub niemożliwości dialogu, pluralizmu i syntezy.

Thomas Kuhn nadał terminowi paradygmat około dwudziestu znaczeń (Kuhn, 2001, 1985, 2003). Z reguły na paradygmat składa się zbiór fundamentalnych założeń, które formują obraz badanego świata. Jest on z definicji szerszy niż konceptualny model świata, ponieważ stanowi podstawę do konstruowania pojęć. Jest także szerszy niż teoria, będąca systemem założeń zbudowanym z pojęć, którym znaczenie nadaje paradygmat. „Fakty” rzadko mówią same za siebie i nabierają sensu jedynie wtedy, gdy interpretujemy je w świetle podstawowych założeń paradygmatu. Paradygmat służy zatem do rozstrzygania, które fakty są bardziej znaczące kosztem innych faktów (Mansbach, Vasquez, 1981: 4, 71).

Tabela 1

Debaty paradygmatyczne w nauce o stosunkach

\begin{tabular}{||l|l|l|l|l||}
\hline Debaty & \multicolumn{1}{|c|}{ Okres } & \multicolumn{1}{|c|}{ Paradygmaty } & \multicolumn{1}{|c|}{ Istota debaty } & \multicolumn{1}{|c|}{ Innowacje } \\
\hline I debata & $1920-1939$ & Idealizm vs realizm & Instytucje vs interesy & $\begin{array}{l}\text { Społeczność państw vs } \\
\text { system państw }\end{array}$ \\
\hline II debata & $1950-1970$ & $\begin{array}{l}\text { Tradycjonalizm vs beha- } \\
\text { wioryzm }\end{array}$ & $\begin{array}{l}\text { Historia vs nauka } \\
\text { nacja }\end{array}$ \\
\hline III debata & Lata 1980 XX w. & $\begin{array}{l}\text { Pozytywizm vs antypo- } \\
\text { zytywizm }\end{array}$ & $\begin{array}{l}\text { Epistemologia: pozyty- } \\
\text { wizm vs antypozyty- } \\
\text { wizm/teoria krytyczna }\end{array}$ & $\begin{array}{l}\text { Eksplancja vs rozumie- } \\
\text { nie }\end{array}$ \\
\hline IV debata & Od lat 1990 XX w. & $\begin{array}{l}\text { Racjonalizm vs kon- } \\
\text { struktywizm vs reflekty- } \\
\text { wizm }\end{array}$ & $\begin{array}{l}\text { Przyczynowe vs konsty- } \\
\text { tutywne wyjaśnianie i/lub } \\
\text { rozumienie }\end{array}$ \\
\hline \hline
\end{tabular}

Źródło: Oprac. na podstawie: E. Kavalski (2007), The fifth debate and the emergence of complex international relations theory: notes on the application of complexity theory to the study of international life, ,Cambridge Review of International Affairs", Vol. 20, No. 3, s. 445.

Na początku lat dziewięćdziesiątych XX w. Georg Sørensen podkreślał, że znacząca większość badaczy stosunków międzynarodowych zgadza się co do istnienia w dyscyplinie trzech paradygmatów („obrazów”, „fundamentalnych perspektyw”): realizmu politycznego (lub „tradycjonalizmu”, ,perspektywy państwocentrycznej”); pluralizmu (lub „liberalizmu”, „perspektywy wielocentrycznej”, „globalnej społeczności”); oraz globalizmu (lub „marksizmu”, „socjalizmu”, „strukturalizmu”) (Sørensen, 1991: 97). Równie powszechnie w NSM akceptuje się pogląd, że w końcowych dekadach minionego wieku na pierwszy plan wysunęła się debata między dwiema najszerzej akceptowanymi teoriami głównego nurtu: neorealizmem i neoliberalizmem. Obecnie przyjmuje się, choć nie bez wyjątków, że w teoretyzowaniu o stosunkach międzynarodowych dominuje debata między racjonalizmem a reflektywizmem, niekiedy z wyłączeniem konstruktywizmu jako osobnej konkurencyjnej perspektywy (racjonalizm-konstruktywizm-reflektywizm). Zazwyczaj konstruktywiści traktują neorealizm i neoliberalizm jako 
podejścia racjonalistyczne do stosunków międzynarodowych, mające ontologię indywidualistyczną i materialistyczną - w przeciwieństwie do własnego podejścia, przede wszystkim holistycznego i idealistycznego (Adler, 1997: 319-363; Dunne, 1995: 367-389; Moravcsik, 1997: 513-553; March, Olsen, 1998: 943-969; Katzenstein, Keohane, Krasner, 1998: 645-685). Jako przeszkodę uniemożliwiającą porównanie neorealizmu i neoliberalizmu wskazuje się niekiedy brak autorytatywnej postaci teorii neoliberalnej. W odróżnieniu od neorealizmu, którego podstawowe założenia w mocnym ujęciu przedstawił Kenneth N. Waltz (2010) w 1979 r., neoliberalizm nie ma podobnie mocnego modelu. Powoduje to liczne problemy związane z rozumieniem neoliberalizmu. Po pierwsze, bywa on definiowany w relacji do neorealizmu i określany jako jego „wirtualny bliźniak” lub jako jego „oponent”. Po drugie zaś, neoliberałowie często wzywają do syntezy swojego podejścia z neorealizmem, chociaż taka synteza stawia pod znakiem zapytania istotę zarówno neoliberalizmu, jak i neorealizmu, głównie z powodu odmiennego rozumienia stosunku między procesem a struktura (Legro, Moravcsik, 1999: 5-55; Waltz, 2000: 5-41)².

W głównym nurcie NSM dominuje przekonanie, że twierdzenia „naukowe” są w zasadniczy sposób odmienne od reflektywistycznych argumentów. „Naukowość” ma gwarantować bardziej ,fundamentalną” wiedzę opartą na „empiryzmie”, surowości dedukcyjnego lub/i indukcyjnego postępowania lub optymistycznym przeświadczeniu, że nauka ze swej natury eliminuje błędy.

Przeciwstawiający się temu poglądowi reflektywiści głoszą, że jeśli epistemologiczne debaty ostatnich dziesięcioleci cokolwiek wykazały, to przede wszystkim podważyły owo przekonanie. Jako uzasadnienie przywołują, po pierwsze, niemożliwość wskazania najlepszej metody naukowej spośród wielu istniejących; ostatecznie to uprawiający daną dyscyplinę, a nie filozofowie nauki decydują a priori, co należy uważać za wiedzę. Przypominają, że poszukiwania metody naukowej niezależnej od danej dyscypliny poprzez racjonalną rekonstrukcję historii nauki doprowadziły do przekonania, że naukowcy nie zachowują się w sposób, jaki te rekonstrukcje sugerują, a historyczny rozwój nauki podważał wszystkie teorie epistemologiczne (Kuhn, 2001). Po drugie, według reflektywistów empiryzm, zakładający iż „rzeczy” ukazują się „same w sobie” pomija fakt, że ,natura” sama nie może niczego komunikować, ponieważ do komunikacji potrzebny jest język. „Prawda” zatem, zamiast własnością, ,zewnętrznego świata”, może być jednym z wielu możliwych „twierdzeń o świecie”.

2 Za fundacyjną dla neoliberalizmu uważa się pracę R. O. Keohane'a i J. S. Nye'a Power and Interdependence, (New York 1989). Keohane i Nye rozwinęli podejście do stosunków międzynarodowych określane jako kompleksowa współzależność (complex interdependence). Sama w sobie kompleksowa współzależność jest typem idealnym skonstruowanym w opozycji do realizmu. Autorzy wymieniają główne założenia realizmu i w kontraście do nich wskazują cechy kompleksowej współzależności. W zakończeniu książki stwierdzają, że koncepcja kompleksowej współzależności jest „wyraźnie raczej liberalna niż realistyczna” $(1989,254)$. Keohane i Nye są przekonani, że neorealizm koncentruje się na poziomie struktur teorii systemowej, neoliberalizm zaś na poziomie procesu. W neorealizmie znajduje to wyraz w nacisku na przyczynowy rozkład możliwości w systemie, w neoliberalizmie w podkreślaniu znaczenia wzorca interakcji między państwami. Interesującą próbę uzgodnienia obu teorii w perspektywie konstruktywistycznej proponuje C. G. Thies (2004: 159-183). 
Oznacza to, że nie możemy testować naszych idei bezpośrednio odnosząc je do rzeczywistości, ponieważ wszystkie pytania, jakie stawiamy rzeczywistości, są zawarte $\mathrm{w}$ teorii lub w języku. Testować możemy tylko teorie przeciw teoriom. Ostatecznie o nauce dowiedzieliśmy się tylko tego, że pytań, które stawiamy dzisiaj, nie mogliśmy postawić kilka dekad wcześniej ${ }^{3}$. Z punktu widzenia zwolenników tego stanowiska znalezienie „regulatywnej idei” nauki jako warunku dialogu wydaje się fantasmagorią i może prowadzić do dogmatyzmu i nieuzasadnionego zamykania się zajmujących odmienne stanowiska.

Za dobre wyjście z takiej sytuacji w NSM uważa się często pluralizm, który wydaje się najbardziej obiecującą strategią dalszych badań i uzyskiwania wiedzy. Pluralizm nie polega jednak na uznaniu, że ,wszystko jest dozwolone”, a skoro nie ma zgody co do fundacyjnych standardów uprawiania nauki, żadne standardy nie obowiązują. Zwolennicy pluralizmu nie wykluczają koincydencji między różnymi perspektywami teoretycznymi, chociaż uznają, że nie ma archimedesowego punktu oparcia, za pomocą którego moglibyśmy rozstrzygać, kiedy „rzeczy” są takie, jakie są. Niektórzy badacze wszakże podkreślają, że nawet jeśli pluralizm teoretyczny uznaje się za zdrowy i korzystny dla rozwoju dyscypliny, ograniczająco działa brak konsensu co do jego warunków i to, że NSM jest ciaggle zdominowana przez teorie głównego, hegemonicznego nurtu (Schmidt, 2007: 105).

Różnice stanowisk powodują, że wiele konferencji naukowych poświęconych różnym problemom międzynarodowym szybko przekształca się w dyskusje nie o tym, co się dzieje na świecie, nawet nie o tym, jakie teorie mogą najlepiej to wyjaśnić, ale w spory o ontologiczne i epistemologiczne fundamenty sądów formułowanych o stosunkach międzynarodowych (Sørensen, 1991: 85).

Szczególnie trzecia debata w NSM przyczyniła się do podjęcia na szerszym forum rozważań na temat filozoficznych i metateoretycznch podstaw dyscypliny. Liczni badacze uznali, że NSM ma wątpliwy honor być najmniej samorefleksyjną dyscypliną wśród nauk społecznych. Trzecia debata stała się zatem bodźcem do teoretycznego i epistemologicznego fermentu, wzbudziła też poczucie więzi z innymi dyscyplinami podlegającymi podobnemu procesowi. Debata zwróciła uwagę na nowe rozumienie obiektywizmu naukowego i doprowadziła do przewartościowania poglądów w kwestii akceptowanych dotąd kryteriów oceny postępu naukowego (Lapid, 1989: 250).

Georg Sørensen zwrócił uwagę na pewien niekorzystny proces związany z trzecią debatą. Otóż wszyscy badacze niepodzielający filozofii nauki postmodernistów (antypozytywistów), czyli idealiści, realiści, tradycjonaliści, behawioryści, scjentyści, neorealiści i globaliści, zostali wrzuceni przez nich do ,jednego wielkiego worka”. Postmoderniści ocenili ich jako pozytywistów i przypisali im rozumienie NSM jako „nauki o wydarzeniach”, o których badacz poszukuje obiektywnej prawdy w znaczeniu: „co rzeczywiście zdarzyło się w realnym świecie”. Pozytywiści wierzą bowiem

3 Jednym z wniosków wynikających z analizy historii teoretyzowania o stosunkach międzynarodowych od Tukidydesa do Johna Rawlsa było przekonanie o zależności konstruowanej przez setki lat wiedzy na ten temat od aktualnego kontekstu społecznego i historycznego (Gałganek, 2009). Zob. również „o kierowanej polityką rozwoju” NSM w okresie międzywojennym i po II wojnie światowej (Kratochwil, 2006: 6). 
według postmodernistów, że wydarzenia są niezależne od ich badawczych przedsięwzięć i że ich szczególna perspektywa nie ma wpływu na obraz tego, co się dzieje. Wierzą zatem, że są obiektywni w swoim postępowaniu badawczym, a tym samym, że zapewnia ono prawomocność rezultatów badawczych.

Broniąc pozytywistycznej perspektywy Andrew Moravcsik, zwolennik teorii neoliberalnej, wskazuje przykłady teoretycznej syntezy w NSM w latach osiemdziesiątych i dziewięćdziesiątych XX w. Zatem, Robert Keohane dociekając przyczyn powojennej współpracy łączył realistyczną teorię hegemonicznej stabilności z teorią reżimów międzynarodowych; teoretycy bezpieczeństwa Stephen Walt, Jack Snyder, Stephen Van Evera, Barry Buzan łączyli „siłę” i „intencje”, wyjaśniając formowanie się aliansów, imperializmu, wojny i globalnej struktury; Bruce Russett i John O’Neal łączyli czynniki liberalne i instytucjonalne w wyjaśnianiu pokoju między liberalnymi państwami; Martha Finnemore i Kathryn Sikkink łączyły podejścia racjonalistyczne i konstruktywistyczne badając ewolucję międzynarodowych norm praw człowieka (Keohane, 1989; Walt, 1987; Van Evera, 1990/1991; Snyder, 1991; Buzan, Jones i Little, 1993; Russett i O’Neill 2001; Finnemore i Sikkink, 1998). Według A. Moravcsika przykłady te pokazuja, że syntezy są możliwe (odrębne teorie łączy się najczęściej formułując zestawy nadrzędnych założeń), trudne natomiast jest porozumienie się co do korzyści i strat wynikających z takiego postępowania. Najpoważniejszą przeszkodą okazywało się zazwyczaj przywiązanie do różnych filozofii nauki. Warto zauważyć jednak, że Moravcsik zajmuje mocne racjonalistyczne stanowisko uniemożliwiające dojście do zgody ze zwolennikiem innej filozofii. Jest on bowiem przekonany, że nauki społeczne mogą znajdować uzasadnienie jedynie jako narzędzie do generowania empirycznej wiedzy o związkach typu przyczyna-skutek. „Zdrowa” NSM jako dziedzina nauk społecznych może być oceniana, jego zdaniem, jedynie w kategoriach jej zdolności do pogłębiania istniejącego empirycznego poparcia dla konkurujących przyczynowych hipotez o stosunkach międzynarodowych. Im szerszy zakres prawomocnie testowanych hipotez, bogatsze źródła danych, bardziej precyzyjne i rygorystyczne rozumienie stosunku między hipotezami a danymi, tym bardziej satysfakcjonujący stan NSM. Nie należy przy tym, jego zdaniem, zarzucać w naukach społecznych debat dotyczących historii intelektualnej, fundamentalnej teorii społecznej, ontologii i epistemologii, uwarunkowań politycznych i normatywnych. Ostatecznie każda dyskusja o możliwości dialogu i syntezy musi odzwierciedlać podstawowe, choć często wyrażane jedynie implicité, metateoretyczne zobowiązania. Jednak te ostatnie nie mogą zajmować miejsca tych pierwszych. A. Moravcsik uważa, że każda debata w naukach społecznych, która zbacza w stronę dyskusji metateoretycznych powinna być traktowana podejrzliwie. Swoje stanowisko w tej kwestii określa jako weberowskie: w świecie wielu dyskursów specyficzne metody badawcze muszą być uzasadniane w kategoriach ich własnych form i celów. Naukowy dyskurs nauk społecznych odróżnia się w tym względzie od innych istotnych metod dyskursu akcentem, jaki kładzie na teorię, metodę i wyjaśnianie empiryczne. Teoria i metoda są zatem środkami, nie celami. Jako środki mają służyć naszemu rozumieniu przyczyn empirycznych przez wzmacnianie podbudowy teoretycznej, logicznej spójności i empirycznej obiektywności (Moravcsik, 2003: 133). Według A. Moravcsika ci, którzy mają mniej optymistyczny pogląd w kwestii progresywnych możliwości nauk społecznych, zbaczają często ku ,abstrakcyjnemu filozofo- 
waniu". Tendencja ta, według Moravcsika, charakteryzuje prawie wszystkich autorów postpozytywistycznych. Co więcej, w kolejnych debatach używane w nich kategorie stają się coraz bardziej abstrakcyjne. Podsumowując swoje stanowisko A. Moravcsik z ledwie ukrywaną ironią stwierdza, że być może niewypowiadaną przesłanką takiego postępowania jest ,głębsze filozoficzne zrozumienie” ułatwiające bogatsze empiryczne poznanie stosunków międzynarodowych, jednak jego pewnym rezultatem jest jedna debata więcej.

W czwartej debacie niektórzy jej uczestnicy traktowali konstruktywizm raczej jako analityczne narzędzie lub soczewki (a nie substancjalną teorię) użyteczne do teoretyzowania o stosunkach międzynarodowych (Fearon, Wendt, 2002). Zwolennicy racjonalizmu argumentowali zaś, że konstruktywizm nie jest potrzebny, ponieważ zarówno liberalna teoria stosunków międzynarodowych, jak i realizm polityczny dostarczają prawomocnych wyjaśnień.

Odrzucając tę argumentację, Friedrich Kratochwil przekonywał, że konstruktywizm jest nie tyle podejściem do stosunków międzynarodowych, ile „stanowiskiem metateoretycznym", a tym samym nie sytuuje się na tym samym poziomie co inne teorie stosunków międzynarodowych. Konstruktywiści nie dziwią się, że występujące zjawiska podlegają konkurencyjnym opisom, a wyjaśniająca moc danego podejścia teoretycznego powinna być oceniana przez jakość prac, jakie w jego ramach powstają (Kratochwil, 2003: 127) ${ }^{4}$. Są jednak przekonani, że pozytywistyczna filozofia nauki kieruje prowadzoną $\mathrm{w}$ ramach dyscypliny debatę ku faworyzowaniu teorii racjonalistycznej, co potwierdza zakres dyskusji toczonych w amerykańskiej NSM. W związku z tym ich zdaniem powinno się dążyć do zwiększania teoretycznego pluralizmu. Pozytywiści odpowiadaja że nie istnieje konieczny związek między pozytywizmem a racjonalizmem. Ponadto zarzucają konstruktywistom, że ich wezwanie do rozszerzenia pluralizmu jest $\mathrm{w}$ istocie arbitralne i stanowi konserwatywne usprawiedliwienie dla zastoju w NSM (Moravcsik, 2003: 135). Zwolennik konstruktywizmu Thomas J. Biersteker wzywając do nowej debaty metateoretycznej przekonywał, że nie jest zainteresowany wykazywaniem wyższości antypozytywizmu, ale raczej ,zademonstrowaniem możliwości alternatywnej konstrukcji pewnych konkretnych problemów, w tym samorefleksyjnych, zniuansowanych i kierowanych teorią badań" (Biersteker, 1989, 226 i n.).

Richard W. Mansbach i John A. Vasquez, uczestnicy czwartej debaty, w propozycji syntezy formułują zalecenia dla przyszłej TSM w formie listy ,złych nawyków wartych odrzucenia”. Do tych nawyków zaliczają: „twardy empiryzm”; „realistyczną [w znaczeniu teorii realizmu politycznego - przyp. A.G.] mitologię”; ,grzech dychotomizacji” (między wewnętrznością a międzynarodowością); „nieprzepuszczalność poziomów analizy”; „etnocentryczność i historyczną selektywność” (Mansbach, Vasquez, 1990: 3-10).

${ }^{4}$ Stanowisko to doprowadziło Kratochwila do sformułowania wartego przytoczenia zalecenia. Otóż na pierwszy rzut oka uzasadnione przygotowanie studentów do posługiwania sięjednym z podejść stosowanych w naukach politycznych, nie jest postępowaniem niewinnym, zwykle bowiem są to teorie akceptowane przez ich opiekunów naukowych. Strategia taka nie stymuluje jednak innowacji, służąc reprodukcji akceptowanej perspektywy i utrudniając studentom stawanie na własnych nogach. Obowiązkiem nauczyciela jest raczej zachęcanie do ufania we własne siły, pobudzanie wyobraźni i wszczepianie krytycznej postawy wobec obowiązujących ortodoksji. 
Pozytywiści podsumowując rezultaty czwartej debaty wprowadzili jednak kolejny podział. Ich zdaniem postmoderniści i reflektywiści znaleźli się w defensywie, ponieważ wzrasta liczba konstruktywistów, którzy wprawdzie podzielają ontologię i teorię postmodernistów, ale akceptują pozytywistyczną filozofię nauki. „Wzmacnianie teoretycznego pluralizmu przez fiat jest nie mniej arbitralne niż wzmacnianie teoretycznej homogeniczności przez fiat" (Moravcsik, 2003: 135). Ostatecznie, w opinii pozytywistów, badacze stosunków międzynarodowych powinni mniej zastanawiać się nad metateoretycznym, ontologicznym i filozoficznym statusem nauk społecznych, a więcej myśleć o syntezach teoretycznych, które pomogą im zrozumieć zjawiska zachodzące w stosunkach międzynarodowych poznawane drogą badań empirycznych.

Można sądzić, że podstawowe założenie dialogu i syntezy powinno znajdować swój wyraz w przekonaniu, że prowadzą one do lepszej wiedzy o świecie. Jednak liczni antypozytywiści uważają, że teorie reprezentują raczej różne perspektywy różnych społecznych światów, co oznacza brak neutralnej podstawy do ich oceny. Dialog i synteza wymagają akceptacji wspólnych założeń epistemologicznych i metodologicznych, a przynajmniej założeń, które się nie wykluczają. Antypozytywiści wskazują że amerykańska NSM w swym głównym nurcie optuje za istnieniem jednej, podstawowej epistemologii. W tym kontekście ontologiczne różnice między podejściem racjonalistycznym a reflektywistycznym do stosunków międzynarodowych są mniej znaczące aniżeli dzielące je różnice epistemologiczne. Ponieważ według reflektywistów reguły ustanawia obecna racjonalistyczna ortodoksja, czyni to dialog niemożliwym. Zaś według zwolenników stanowiska racjonalistycznego, takich jak Peter Katzenstein, Robert Keohane i Stephen Krasner, reflektywizm znajduje się poza naukami społecznymi i w rezultacie nie może być partnerem żadnego dialogu. Zdaniem R. Keohane'a, dopóki reflektywiści nie sformułują konkretnych empirycznych programów badawczych, dopóty pozostaną na peryferiach dyscypliny (Keohane, 1988: 379-396). Również Stephen Walt delegitymizuje podejście reflektywistyczne. Przyznając, że podstawowa debata w TSM toczy się nadal między realizmem a liberalizmem, jednocześnie dowodzi, że wyłoniło się trzecie podejście, którym w jego ocenie nie jest reflektywizm, ale konstruktywizm. Walt sprowadza istotę reflektywizmu do „dekonstrukcji”, której zasadniczym celem są teorie głównego nurtu: „Ponieważ badacze ci [reflektywiści - przyp. A.G.] koncentrowali się początkowo na krytyce paradygmatów głównego nurtu nie proponując pozytywnych alternatyw dla niego, pozostawali świadomie dysydencką mniejszością przez większość lat osiemdziesiątych XX w." (Walt, 1998: 32).

Należy zatem być „nieco” sceptycznym co do dialogu między rywalizującymi stanowiskami paradygmatycznymi i ,całkowicie” sceptycznym co do możliwości syntezy. Z punktu widzenia dialogu w NSM istotne są trzy kwestie: 1) każde postępowanie badawcze powinno wynikać z potrzeb empirycznych (lub kierować się problemem) i nie określać a priori rodzaju problemów empirycznych jako przedmiotu badań; 2) postępowanie to powinno być otwarte na wszystkie interpretacje wydarzeń i nie wykluczać ex cathedra żadnego podejścia; 3) każde postępowanie powinno być interdyscyplinarne, ponieważ badanie stosunków międzynarodowych nie powinno być ograniczane do jednej dyscypliny. Interdyscyplinarność poszerza aspekty epistemologiczne i metodologiczne pola badawczego osłabiając roszczenie NSM do wyjątkowości (Smith, 2003: 143). W ocenie zwolennika antypozytywizmu dialog nie będzie łatwy 
ani nawet możliwy, dopóki NSM nie przestanie być dyscypliną zdominowaną przez wąską ortodoksję odzwierciedlającą historycznie i kulturowo specyficzne interesy. „Taka zmiana będzie następowała, ale dopóki nie zostanie przeprowadzona, dopóty dyscyplina będzie kontynuowała odzwierciedlanie jednego, ograniczonego, częściowego poglądu o strukturach i procesach jednego świata stosunków międzynarodowych" (Smith, 2003: 143). Przyjmując perspektywę filozofii nauki S. Smith podkreśla, że nie istnieje żaden „kamień filozoficzny”, na którym można by budować fundament roszczenia do prawdy. Stanowisko takie nie jest jednak równoznaczne z przekonaniem, że nie istnieją żadne standardy oceny jakości badań. Żadna teoria nie powinna być chroniona przez „epistemologiczną bramę”. Ostatecznie więc, postulowanie teoretycznej syntezy w NSM jest błędem, ponieważ zakłada, że można dojść do prawdy o świecie łącząc różne teorie i podejścia.

Filozof nauki Peter Kosso w swojej propozycji oceny teorii wprowadza dystynkcję między wewnętrznymi a zewnętrznymi cechami każdej teorii. Cechy wewnętrzne można ocenić nie odwołując się do obserwacji świata, zewnętrzne zaś wymagają tego rodzaju obserwacji. Ocenę cech zewnętrznych powinna poprzedzać ocena cech wewnętrznych, wymaga bowiem jedynie ich odniesienia do założeń teorii oraz wiedzy zgromadzonej w danej dyscyplinie. Niedostatki cech wewnętrznych powodują, że nie jest już podejmowana ocena jej cech zewnętrznych przez odniesienie do obserwowalnego świata. Podstawowym wymogiem wobec wewnętrznych cech teorii jest logiczna spójność - warunek niekontrowersyjny, ale w praktyce trudny do realizacji. Stephen Walt wymienia dwa dodatkowe kryteria, szczególnie istotne w ocenie wartości teorii: oryginalność i empiryczną prawomocność. Podobne stanowisko zajmuje Kenneth N. Waltz: „Wielu z tych, którzy testują teorie, uważa, że trudność tkwi przede wszystkim w projektowaniu testu, jednakże ja będę się upierał, że najważniejszy problem polega na znalezieniu lub sformułowaniu teorii na tyle precyzyjnej i wiarygodnej, by w ogóle opłacało się ją testować. Niewiele teorii polityki międzynarodowej definiuje terminy i precyzuje powiązania między zmiennymi na tyle jasno i klarownie (with the clarity and logic), by spełnić ów warunek (that would make testing the theories worthwhile)" (Waltz, 2010: 21; Waltz, 1979: 14).

Testowanie neorealizmu i neoliberalizmu w perspektywie konstruktywistycznej przy zastosowaniu modelu przetrwania (survival model) Williama N. McPhee (1963) przekonuje, że obie teorie są wewnętrznie spójne z kulturami anarchii, które przewidują. Różnicę między nimi powoduje odmienne rozumienie procesu i struktury w systemie międzynarodowym; w istocie zaś obie rywalizujące teorie są dwoma wariantami tego samego modelu. Jednak w praktyce ów podział, odzwierciedlany w istniejących czasopismach naukowych, nauczaniu uniwersyteckim, praktykach zatrudniania i wymogach publikacyjnych, jest utrzymywany i wręcz wzmacniany, przechodząc w sposób niekontestowany na kolejną generację badaczy (Thies, 2004: 179).

Teoretykiem poszukującym pośredniego stanowiska wśród uczestników czwartej debaty jest Alexander Wendt, który w dwadzieścia lat po opublikowaniu książki Kennetha N. Waltza przeprowadził konstruktywistyczną korektę podstawowych aspektów jego projektu teoretycznego. W ujęciu Wendta teoria polityki międzynarodowej wyjaśnia społecznie konstruowany system międzynarodowy za pomocą teorii społecznej. W tej koncepcji czynniki ideacyjne triumfują nad siłami materialnymi w rozumieniu 
społecznie konstruowanej struktury międzynarodowej, a podejście indywidualistyczne przegrywa z perspektywą holistyczną.

Na pierwszy rzut oka wydaje się, że Wendt jest daleki od materialistycznego stanowiska realizmu politycznego. Jednak zwolennikom konstruktywizmu rozumianego jako teoria krytyczna trudno zaakceptować nieukrywaną przez Wendta postawę metateoretyczna, kwestionowaną przez teorię krytyczną. Wendt określa się bowiem jako pozytywista, scjentysta i esencjalista, i podziela poglądy realizmu politycznego w kwestii państwocentryzmu i interesu narodowego. Oddziela też politykę wewnętrzną od zewnętrznej i dowodzi, że system międzynarodowy może być traktowany jako relatywnie autonomiczny. W tym sensie stanowisko Wendta jest mniej warunkowane ogólną teorią społeczną stosunków międzynarodowych, a bardziej szczególną społeczną teorią systemu międzynarodowego (Campbell, 2001: 441). W rezultacie Wendt uzasadnia tezę, że państwa są przedspołeczne i ontologicznie wcześniejsze od systemu międzynarodowego. Campbell tłumaczy jego stanowisko dwoma czynnikami. Pierwszym było dążenie Wendta do znalezienia via media - ,pośredniej drogi” między rywalizującymi teoriami stosunków międzynarodowych. W związku z tym we wszystkich teoriach upatruje on genealogii konstruktywizmu, który zajmuje się problemami od dawna podejmowanymi w NSM. Stara się tym samym udowodnić w ten sposób głównemu nurtowi, że błędem jest uznawanie każdej społecznej konstrukcji za abdykację na rzecz postmodernizmu. Drugi czynnik, bardziej znaczący, wiąże się z tym, że socjologiczne ujęcia polityki międzynarodowej, które identyfikuje Wendt, zwłaszcza zaś wyróżnienie materializmu i idealizmu jako ontologicznych ram ludzkiego działania w świecie, strukturyzuje jego interpretację w szczególny sposób jako naturalistyczną.

Wendt realizuje zatem dwa trudne do pogodzenia cele. Chce ukazać społeczny charakter struktury międzynarodowej i ideacyjny charakter siły i interesów w systemie międzynarodowym, a jednocześnie pozostać wierny naukowemu realizmowi i poszukiwać eksplanacji przyczynowych i konstytutywnych. Dla Wendta konstruktywizm „bez natury” idzie zbyt daleko.

Jednak radykalnym konstruktywistom trudno zaakceptować stanowisko A. Wendta, jeśli zderzają je z przyjmowaną przez antropologów, geografów i teoretyków polityki tezą o konstruowanym charakterze natury. Według Campbella stanowisko A. Wendta jest nie tyle ontologiczne, ile „ontopolityczne” w kwestii natury rzeczywistości i naszej zdolności jej zrozumienia (Campbell, 2001: 242-343).

Podjętą przez Wendta próbę wyjścia poza podział między pozytywizmem a antypozytywizmem (trzecia debata) w formie opartej na filozofii naukowego realizmu teorii „umiarkowanego konstruktywizmu” oraz propozycję teorii krytycznej stosunków międzynarodowych wyrastającą z koncepcji etyki dyskursywnej Jürgena Habermasa interpretuje się niekiedy jako początek czwartej debaty w NSM (Wæver, 1997: 1-37; Diez, Steans, 2005: 127-140).

Czwarta debata została opisana po raz pierwszy przez Ole Wævera w $1996 \mathrm{r}$. Jej istotę można sprowadzić do "debaty między wyjaśnianiem a rozumieniem, między pozytywizmem a postpozytywizmem lub między racjonalizmem a reflektywizmem" (Kurki, Wight, 2007: 20). Niektórzy traktują tę debatę jako ostateczne przełamanie monopolu podejść racjonalistycznych (neorealizmu i neoliberalizmu) w NSM. W tej interpretacji jej najważniejszym rezultatem jest teoretyczna różnorodność dyscypliny oraz 
radykalne zakwestionowanie najbardziej fundamentalnych założeń w NSM, takich jak przedmiot i granice dyscypliny oraz dominujące założenia epistemologiczne i ontologiczne. Jednak to, co jedni sławią, inni atakują kontrargumentując, że zbyt wiele pluralizmu doprowadziło do podziału dyscypliny. W konsekwencji nie tylko nie może ona przemawiać jednym głosem, ale nawet uzgodnić, co powinno być badane i wyjaśniane. Innymi słowy, pluralizm maskuje fakt, że NSM stała się niespójnym polem badawczym (Schmidt, 2007: 108).

Barry Buzan i Richard Little najważniejszą przyczynę upadku NSM jako intelektualnego projektu widzą w nieustannych zapożyczeniach od innych dyscyplin [2001: 19-39]. Przeciwnie, Brian Schmidt podkreśla, że to przez tych, którzy „pozostali wierni naukowemu badaniu polityki światowej i pozostają pod wpływem sformułowanych przez Thomasa Kuhna warunków rozwoju naukowego, pluralizm jest traktowany jako przeszkoda naukowego postępu" (Schmidt, 2007: 109). W tym kontekście niektórzy wskazują, że popularność wendtowskiej wersji konstruktywizmu jako próby znalezienia via media między racjonalizmem a reflektywizmem może uczynić z konstruktywizmu teorię dominującą w NSM. Podobnie zwrot od Kuhna do alternatywnych modeli postępowania naukowego formułowanych w filozofii nauki, takich jak koncepcja „metodologii naukowych programów badawczych" Imre Lakatosa i filozofia naukowego realizmu Roya Bhaskara, mogą być przez różne podejścia teoretyczne traktowane jako dążenie do postępu naukowego (ibidem).

Inni studzą ten optymizm wskazując, że oprócz podziałów międzyepistemicznych (inter-epistemic, np. między głównym nurtem a teoriami krytycznymi) istnieją w NSM być może jeszcze bardziej dzielące, intraepistemiczne (intra-epistemic lub intra-paradigmatic) debaty. Prowadzą je między sobą zarówno pozytywiści, jak i postpozytywiści oraz przedstawiciele teorii krytycznej (Harvey, Cobb, 2003: 144).

Toczone w TSM debaty paradygmatyczne podzieliły zatem dyscyplinę. Badania przeprowadzone przez Richarda Jordana i jego współpracowników w 2008 r. ukazały istotne znaczenie tych podziałów (Jordan et al., 2009). W przeprowadzonej przez badaczy ankiecie uczestniczyło 2724 przedstawicieli NSM z dziesięciu państw (Stany Zjednoczone, Wielka Brytania, Kanada, Australia, Nowa Zelandia, Irlandia, Izrael, Republika Południowej Afryki, Hongkong, Singapur). Jako przyczynę najważniejszych podziałów w obrębie dyscypliny $69 \%$ respondentów wskazało metody, $67 \%$ epistemologię, $52 \%$ paradygmaty i $39 \%$ ontologię. Zgodnie z deklaracjami badanych w Stanach Zjednoczonych było wśród nich 21\% realistów, 20\% liberałów i 17\% konstruktywistów; $26 \%$ nie identyfikowało się z żadnym z tych paradygmatów. Równocześnie pod względem epistemologii 65\% badaczy stosunków międzynarodowych w Stanach Zjednoczonych określiło swoje stanowisko jako pozytywistyczne. Jeśli chodzi o relację: racjonalizm versus konstruktywizm, 58\% badaczy amerykańskich identyfikowało się z racjonalizmem, $18 \%$ zaś z konstruktywizmem ${ }^{5}$.

\footnotetext{
5 Warto również przytoczyć dane dotyczące czasu poświęcanego poszczególnym teoriom stosunków międzynarodowych na wykładach wprowadzających do NSM: realizm - 22\%; liberalizm $-19 \%$, konstruktywizm $-11 \%$, marksizm $-9 \%$, feminizm $-6 \%$, szkoła angielska $-6 \%$, podejścia nieparadygmatyczne $-17 \%$ oraz inne paradygmaty $-12 \%$ (Jordan et al., 2009: 18).
} 
W celach ilustracyjnych najważniejsze podziały paradygmatyczne w NSM przedstawiono w formie graficznej (rys. 1).

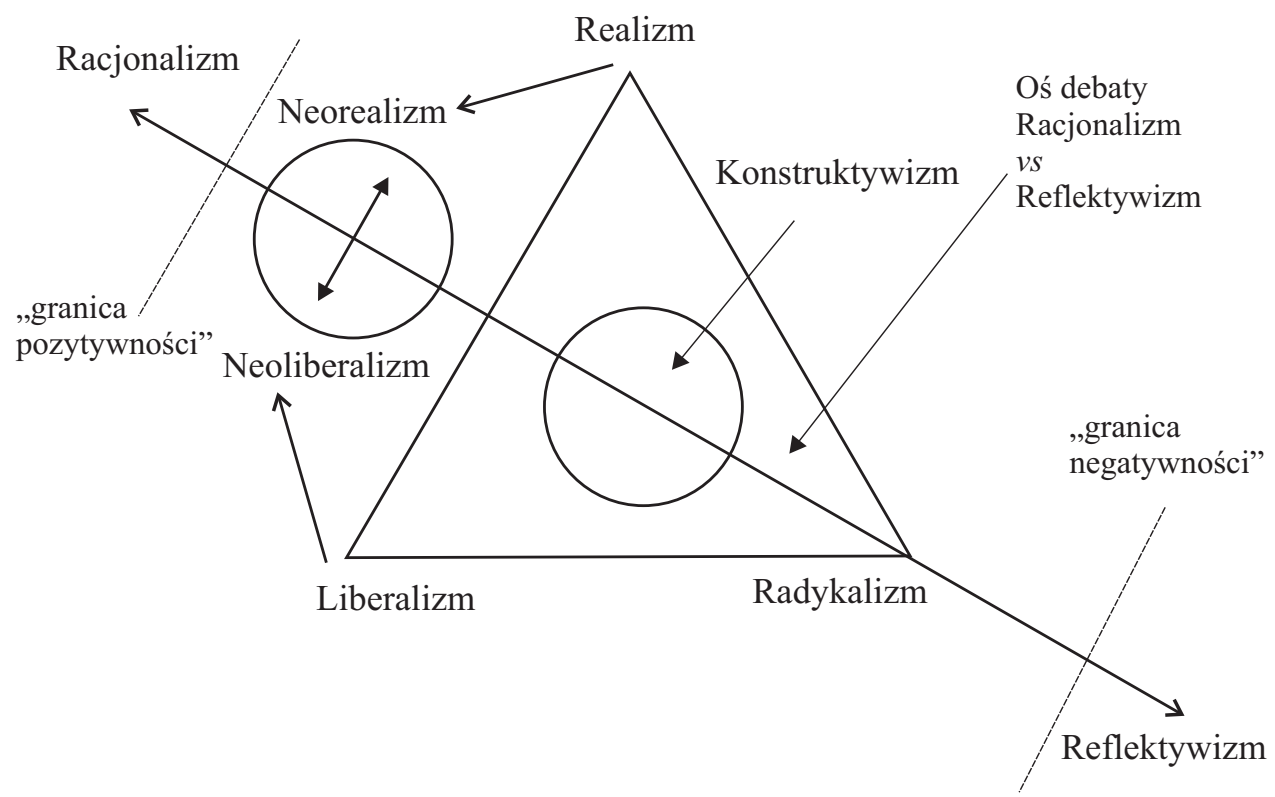

Rys. 1. Podziały paradygmatyczne w NSM

Źródlo: Oprac. na podstawie: H. Patomäki, C. Wight (2000), After Postpositivism? The Promises of Critical Realism, „International Studies Quarterly”, Vol. 44, No. 2, s. 214; O. Wæver (2009), Waltz's Theory of Theory, „International Relations", Vol. 23, No. 2, s. 215.

\section{CZY OBIETNICE FILOZOFII NAUKI SĄ UZASADNIONE?}

Czy teoretycy NSM mogą sami rozstrzygnąć, że w ich dyscyplinie dokonuje się postęp? Czy mogą odpowiedzieć na pytanie o jej progresywność w znaczeniu dostarczania kumulatywnej wiedzy o dotąd niewyjaśnionych zjawiskach? Czy odpowiadając na te pytania muszą posłużyć się ,teoriami zmiany naukowej”? (Elman, Elman, 2003: 1). Mówiąc inaczej, czy po odpowiedzi muszą udać się do filozofii nauki?

Filozofia nauki konstytuuje dla nauki superstrukturę - teoretyczne ramy, przez które nauka jest postrzegana i rozumiana. W tych ramach są formułowane kryteria naukowości. Określają one, co jest naukowe, a co nie jest, jakie metody badawcze można uznać za uprawnione, jakie problemy są odpowiednio postawione, a ich rozwiązania właściwe. Filozofia nauki bada krytycznie podstawy, metody, wytwory i implikacje aktywności nazywanej nauką. Do podstawowych problemów badawczych filozofii nauki należą: źródła i natura języka naukowego (np. kategorii, pojęć, generalizacji, praw, teorii, eksplanacji, przewidywań); prawomocność języka naukowego (np. definicji, znaczeń, zastosowań); metody naukowe; rozumowanie naukowe oraz modele aktywności naukowej (Moore, 2010: 137). 
Nawet ci przedstawiciele nauk społecznych, którzy deklarują obojętność wobec filozofii nauki, muszą posługiwać się narzędziami metodologicznymi opartymi na wcześniejszym rozstrzygnięciu, czym jest postęp w nauce i jak go mierzyć. Już na wstępie odwołując się do Imre Lakatosa można powiedzieć, że w jednym okresie filozofia nauki może progresywnie oddziaływać na daną dyscyplinę, w innym powodować jej stagnację lub nawet prowadzić do jej degeneracji (Elman, Elman, 2002: 231-263; Vasquez, 1998).

Dlaczego - pyta Alexander Wendt - miałoby mieć znaczenie, czy badacze stosunków międzynarodowych nazywają siebie, na przykład, naukowymi realistami lub antyrealistami? Przecież brak zgody fizyków realistów i antyrealistów co do ontologicznego statusu kwarków nie wpływa na prowadzone przez nich badania. Jednak w odróżnieniu od nauk przyrodniczych, badacze w naukach społecznych są mniej pewni, jak powinno przebiegać ich postępowanie badawcze, i kierują się często do filozofów po wskazówki metodologiczne. Na przykład, przedstawiciele głównego nurtu w TSM korzystają z rad empirystów. Rozwój metod ilościowych w podejściu behawioralnym w latach pięćdziesiątych XX w. odzwierciedlał dominujące przekonanie przedstawicieli pozytywizmu logicznego, że podstawą naukowego wyjaśniania muszą być prawa. Podobnie obecne zainteresowanie analizą dyskursu jest wyrazem interpretywizmu głoszącego, że życie społeczne nie podlega wyjaśnieniom przyczynowym (Wendt, 2008: 54). Przedstawiciele nauk przyrodniczych doświadczają kryzysów dyscyplinarnej tożsamości w daleko mniejszym stopniu niż badacze społeczni. Ci ostatni, w większym stopniu ulegając zwątpieniu, zwracają się częściej w stronę filozofii nauki. Również wielu filozofów nauki, nawet krytycznie nastawionych do praktyk nauk społecznych, wierzy, że ich programy filozoficzne pomogą badaczom z dziedzin społecznych „unaukowić” ich praktyki. Na przykład, Imre Lakatos chociaż stawiał nauki społeczne na równi z astrologiq, uważał, że jego metodologia naukowych programów badawczych daje najlepszy sposób wprowadzenia do nich pewnych standardów (Pleasants, 2003: 69). Filozofowie nauki są pewni, że swą analizą mogą „wyleczyć” nauki społeczne z ich „ewidentnej choroby” (Roy Bhaskar). Dowodzą oni, że nie istnieje żadna przyczyna, by nauki społeczne nie były prawdziwie naukowe. Radzą jednak ich przedstawicielom poważnie potraktować arystotelesowskie ostrzeżenie, że żadna dyscyplina nie powinna dążyć do większej precyzji niż pozwala jej na to natura przedmiotu, który bada. Nie powinni zatem - co często robią - tylko naśladować tego, co naiwnie uważają za podstawowe cechy metodologii „nauk twardych”. Tym, czego nauki społeczne potrzebują, jest według filozofów nauki identyfikacja atrybutów badanych „przedmiotów”; właściwy „metafizyczny obraz” zjawisk „społecznych” i „naturalnych” oraz różnic między nimi; ustalenie kryteriów naukowości pozwalających odróżnić aktywność naukową od nienaukowej (ibidem, 70).

Nuno P. Monteiro i Kevin G. Ruby poszukując odpowiedzi na pytanie, dlaczego NSM wstrząsają nieustające debaty, wskazują na trzy istotne wydarzenia, które ukazują genezę podziałów w obrębie dyscypliny. Pierwszym była rewolucja behawioralna lat pięćdziesiątych i sześćdziesiątych XX w. Wtedy właśnie filozofia nauki została po raz pierwszy przywołana do NSM w celu określenia jej naukowości. Próba nadania NSM bardziej „naukowego” charakteru polegała na imporcie metod i standardów nauk 
przyrodniczych. Behawioryści dowodzili, że jedynie oparcie badań stosunków międzynarodowych na dominującym wówczas w filozofii nauki modelu pozytywizmu logicznego pozwoli przekształcić NSM w dyscyplinę naukową. Niestety, filozofowie nauki szybko porzucili pozytywizm logiczny i zwrócili się ku istrumentalizmowi jako sposobowi wyjścia poza wąski empiryzm i przywrócenia nauce teorii.

Krytyka pozytywizmu zapoczątkowała drugie istotne wydarzenie - otwarcie przestrzeni wypełnionej przez antypozytywistów (teoria krytyczna, feminizm, poststrukturalizm, postmodernizm). Antypozytywiści poszukując fundamentów dla swoich koncepcji także zwrócili się do filozofii nauki, upatrując w społecznym konstruktywizmie walorów pozwalających im konkurować z instrumentalizmem. Według antypozytywistów NSM powinna porzucić jakiekolwiek roszczenia do „naukowości” i skoncentrować się na interpretacji i krytyce.

Trzecie wydarzenie wiązało się z próbą przezwyciężenia ostrej debaty między pozytywistami a antypozytywistami. Część badaczy stosunków międzynarodowych po raz kolejny zwróciła się ku filozofii nauki, poszukując stanowiska umożliwiającego pogodzenie przeciwstawnych sobie nurtów. Najbardziej obiecujący pod tym względem wydawał się naukowy realizm - który jednak doprowadził do nowych fundacyjnych podziałów, nie usuwając dotychczasowych (Monteiro, Ruby, 2009: 20-21).

Co gorsza, jak zauważają Colin i Miriam Elmanowie, w NSM istnieje silna skłonność do wchodzenia w metateoretyczne rozważania bez metateorii, do oceniania teoretycznych propozycji bez posługiwania się przeznaczonymi do tego, wręcz niezbędnymi narzędziami. Tymczasem niemożliwe jest angażowanie się w oceny konkurencyjnych teorii bez dokonania explicite wyboru między konkurencyjnymi epistemologiami (Progress, 2003: 4).

Wielu przedstawicieli NSM, posługując się dwoma błędnymi i przeciwstawnymi sobie argumentami, traktuje nauki polityczne (political science) i filozofię nauki jako dyscypliny podążające odmiennymi drogami. Pierwszy, dwuczęściowy argument głosi, że zbyt mocno chcemy być scjentystami, a posługiwanie się metateorią jest sprzeczne z nauką. Pierwsza część tego argumentu sugeruje, że odwoływanie się do filozofii nauki jest motywowane przez „zazdrość wobec fizyki” i chęć uczynienia z NSM dyscypliny w możliwym stopniu podobnej do bardziej ,poważnych” nauk przyrodniczych. Jednakże to dążenie do podobieństwa nie jest jedynie konsekwencją zazdrości. Jest ono $\mathrm{w}$ istocie argumentem na rzecz metodologicznego monizmu, który głosi, że aczkolwiek różne nauki posługują się odmiennymi metodami badawczymi, mają jako wspólny kontekst te same uzasadniania uzyskiwanej wiedzy. Większość teoretyków głównego nurtu w NSM oczekuje zatem, że ich praca badawcza będzie oceniana według reguł wspólnych całej nauce. Drugi argument przekonuje, że posługiwanie się metateorią podkopuje status naukowców i żaden „szanujący się” badacz nie powinien angażować się $\mathrm{w}$ debaty filozoficzne. W praktyce jednak przedstawiciele wszystkich nauk traktują refleksję nad kryteriami oceny wiedzy naukowej, odróżniania dobrej wiedzy od złej i postępu w ich dyscyplinie jako swój ważny obowiązek (ibidem: 233).

Ilustracyjne wprowadzenie do historii filozofii nauki i jej problemów można rozpocząć od propozycji pozytywizmu logicznego (empiryzmu logicznego) sformułowanej przez reprezentujących różne dyscypliny naukowe członków i gości Koła Wiedeńskie- 
go w latach dwudziestych XX w. ${ }^{6}$ Propozycja ta stanowiła mocną reakcję na neoromantyzm i zbyt „luźne” dziewiętnastowieczne spekulacje o świecie. Pozytywizm logiczny wymagał od wiedzy pewności i empirycznej weryfikalności. W XX wieku pozytywizm w naukach społecznych został stopniowo utożsamiony z obserwowalnością, kwantyfikacją i mierzeniem.

Krytyka pozytywizmu w latach sześćdziesiątych XX w. miała różne przyczyny o charakterze społeczno-politycznym, ale wskazywała również, że w wielu obszarach pozytywizm przekształcił się z metateorii progresywnej w dogmatyczną i stagnacyjną. Celem reakcji antypozytywistycznej było uwolnienie nauki od jej założeń o neutralności i obiektywnej podstawie obserwacyjnej oraz stworzenie teorii, które umożliwią dostęp do nowych typów obserwacji, zarówno w naukach społecznych, jak i w fizyce kwantowej. W rezultacie krytyki pozytywizmu i racjonalizmu krytycznego, którą często symbolizują propozycje filozofów nauki Thomasa Kuhna i Paula Feyerabenda, narodziła się relatywistyczna filozofia nauki, która w swej ekstremalnej formie głosiła, że w postępowaniu naukowym wszystko jest dopuszczalne.

Te dwie filozoficzne postawy w kwestii nauki, określone jako pozytywizm i antypozytywizm, zdominowały biegunowo sposób myślenia o nauce w naukach społecznych, w tym również w NSM. Najkrócej mówiąc, w sferze rozstrzygnięć ontologicznych: po stronie pozytywistycznej znajdują się zwolennicy fenomenalizmu; po stronie antypozytywistycznej zwolennicy idealizmu. W sferze rozstrzygnięć epistemologicznych: strona pozytywistyczna dokonuje ostrej demarkacji między wiedzą naukową a innymi rodzajami wiedzy; strona antypozytywistyczna zaprzecza możliwości przeprowadzenia takiego rozdziału, podkreślając relatywność wiedzy i poznawczą równorzędność różnych sposobów jej uzyskiwania. Metodologicznie: po stronie pozytywistycznej kładzie się nacisk na analizy empiryczne i metodologię ilościową; po stronie antypozytywistycznej na analizę dyskursu, narracji, tekstu i odsłanianie sposobu konstruowania wiedzy.

Trzecią filozofią nauki, będącą próbą wyjścia poza ograniczenia i niedostatki pozytywizmu i antypozytywizmu staje się postpozytywizm, który opiera swój program na propozycji realizmu naukowego. Te trzy stanowiska filozofii nauki - pozytywistyczny instrumentalizm, antypozytywistyczny konstruktywizm społeczny i postpozytywistyczny realizm naukowy - określające filozoficzne fundamenty właściwego postępowania naukowego, są najczęściej przywoływane w NSM (Monteiro, Ruby, 2009: 26).

Badacze stosunków międzynarodowych zwracali się do filozofii nauki z przekonaniem, że może ona dostarczyć użytecznych narzędzi do oceny teoretycznego postępu w dyscyplinie. Nawet pobieżny przegląd literatury w NSM pozwala zaobserwować często przywoływane w tym względzie pojęcie paradygmatu Thomasa Kuhna czy metodologię naukowych programów badawczych Imre Lakatosa.

${ }^{6}$ Ernst Mach jako prekursor; Moritz Schlik, Rudolf Carnap, Victor Kraft, Felix Kaufmann, Karl Popper, Kurt Gödel, Gustaw Bergmann - członkowie; Ernest Nagel, W. V. O. Quine, Carl Hempel, Alfred Tarski - goście. (Gunnnell, 2009: 317-337). 


\section{Instrumentalizm (pozytywizm)}

Metodologiczni naturaliści (tacy jak empiryści logiczni, Karl Popper, ale także wielu współczesnych ,naukowych realistów”) dowodzą, że nauki przyrodnicze i nauki społeczne mogą być porównywane pod względem „szacunku epistemologicznego”. Jednocześnie z przypisywania większego szacunku naukom przyrodniczym wynika potrzeba udoskonalenia się nauk społecznych przez przyjęcie metod, które przyniosły sukces tym pierwszym ${ }^{7}$.

Wpływ pozytywizmu logicznego, przede wszystkim w Stanach Zjednoczonych, na filozoficzny obraz metody naukowej, na teorię i praktykę nauk społecznych szczególnie dotknął nauki polityczne, które po drugiej wojnie światowej coraz bardziej obawiały się o swoją tożsamość. Z jednej strony, biorąc pod uwagę polityczny i społeczny kontekst narodzin pozytywizmu logicznego oraz formułowane przez przedstawicieli Koła Wiedeńskiego cele ich projektu, może wydawać się swoistą ironią, że fílozofia nauki związana z ideologiczną wizją społeczną stała się podstawą amerykańskiego wyobrażenia „czystej” nauki, „wolnej od wartości”. Z drugiej strony mniej to zaskakuje, jeśli pamiętamy, że w amerykańskich naukach społecznych poszukiwanie obiektywności było zawsze, jak w przypadku takich badaczy europejskich, jak Max Weber i Karl Mannheim, motywowane dążeniem do ustalenia neutralnego epistemicznego autorytetu, który z tego względu mógłby być uprawniony do mówienia prawdy władzy. Amerykanie wierzyli, że podstawa do wpływania na politykę powinna mieć charakter apolityczny, a to ściśle korespondowało z pozytywistyczną ,obiektywnością” nauki. Oddziaływanie pozytywizmu logicznego na obraz nauki było szczególnie widoczne w połowie lat pięćdziesiątych XX w. w głównym nurcie amerykańskich nauk politycznych. Oprócz naturalnego związku między problemami politycznymi a naukami politycznymi, w okresie zimnej wojny filozoficzne założenia pozytywizmu logicznego dostarczały wsparcia najważniejszym argumentom używanym do obrony amerykańskiej wersji liberalnej demokracji w jej konfrontacji z ideologią komunistyczną (Gunnell, 2009: 326-327).

W ocenie filozofa nauki Johna G. Gunnella w latach trzydziestych XX w. fala niemieckich badaczy, którzy przybyli do Stanów Zjednoczonych, tak różnych jak Leo Strauss, Eric Voegelin, Hannah Arendt, Theodor Adorno, Max Horkheimer i Herbert Marcuse, zainicjowała - z różnych pozycji ideowych - krytykę zarówno amerykańskiej koncepcji nauki, jak i liberalnej demokracji. Rzadko się przyznaje, że obrona amerykańskich naukowców przed tym atakiem, miała źródła także w niemieckiej filozofii pozytywizmu logicznego. Z tego punktu widzenia „,behawioralna rewolucja” w amerykańskich naukach politycznych, w tym NSM, była raczej próbą konsolidacji, obrony i upowszechniania metod badawczych, zaproponowanych w latach dwudzies-

7 Metodologiczni antynaturaliści (tradycja hermeneutyczna i niektórzy współczesni antyrealiści) odpowiadają, że nauki społeczne nie powinny odwoływać się do metod nauk przyrodniczych; tym samym nie mogą być porównywane epistemologie obu nauk. Należy także pamiętać, że niezależnie od swojego stosunku do nauk społecznych, filozofia nauki jest skoncentrowana przede wszystkim na naukach przyrodniczych, traktując je jako wzorcowy przykład postępowania badawczego (Preston, 2003: 261). 
tych XX w. Reasumując, kiedy amerykańscy politolodzy poczynając od połowy XX stulecia zwrócili się do filozofii nauki w poszukiwaniu autorytatywnej wiedzy o istocie naukowej eksplanacji, debaty charakteryzujące okres behawioralny stały się w efekcie polem konfrontacji europejskich filozofii (ibidem: 330-331).

Za najbardziej znanego reprezentanta instrumentalizmu teoretycznego należy uznać Carla Hempla. Hempel umieszczał poszczególne dyscypliny naukowe na skonstruowanej przez siebie skali. Najwyższe miejsce przyznał fizyce, jako najbliższej spełnienia wymogów logicznej struktury jego „metody hipotetyczno-dedukcyjnej”; najniższe zajmowała historia i nauki społeczne.

Pozytywizm w naukach społecznych opiera się na dwóch dyspozycjach mających zapewnić naukową obiektywność i bezstronność: dyspozycji do odróżniania faktów i wartości oraz dyspozycji do oddzielania politycznych i ideologicznych przekonań teoretyków od przedmiotu ich badań, czyli świata społecznego (Idh-Shalom, 2006: 463).

Istotą stanowiska instrumentalnego nie jest teza mówiąca, że wartość nauk przyrodniczych leży w ich sile technologicznej, ale przekonanie, że nauki przyrodnicze mają większą siłę predyktywną/wyjaśniająca. Teorię, w której występują byty nieobserwowalne, empirysta traktuje ,instrumentalnie” zamiast realistycznie, to znaczy jako narzędzie organizacji doświadczenia, a nie konstrukt odnoszący się do ukrytych struktur rzeczywistości. Zatem epistemologicznie obserwacja ma pozycję poznawczo uprzywilejowaną wobec teorii. Oznacza to, że jeśli teoria nie może być zredukowana do twierdzeń obserwacyjnych, należy ją uważać wyłącznie za instrument. „W odniesieniu do bytów nieobserwowalnych instrumentalizm stawia epistemologię zdecydowanie przed ontologią [...]. To, o czym możemy twierdzić, że istnieje, zależy od tego, o czym możemy wiedzieć, a wiedzieć możemy tylko o tym, co możemy zobaczyć" (Wendt, 2008: 65). Instrumentalizm jest zatem poglądem głoszącym, że teorie naukowe są narzędziami organizującymi doświadczanie obserwowalnych zjawisk i służącymi do predykcji. Wartość teorii naukowej polega na tym, co może ona powiedzieć o dających się zaobserwować zjawiskach (instrumentalizm eliminacyjny). Na przykład, molekularna teoria gazu, która opisuje gaz jako szybko poruszające się molekuły, nie powinna być traktowana jako literalny opis rzeczywistości. Teoria ta jest modelem matematycznym, który symbolicznie przedstawia ciśnienie i temperaturę gazu w celu obliczenia jego ciepła. Formą instrumentalizmu nieeliminacyjnego jest empiryzm konstruktywny, który traktuje język nauki literalnie, to znaczy uważa, że teorie naukowe nie są konstruowane jako metafory (Bas van Fraassen). Fraassen uważa, że naukowcy mogą wykorzystywać heurystyczne funkcje teoretycznych pojęć, niekoniecznie wierząc w nie (Lee, 2007: 300-301).

Pierwsze niebezpieczeństwo, jakie A. Wendt wiąże z instrumentalizmem, polega na myśleniu typu ,jak gdyby”. Jeśli teorie są wyłącznie instrumentami organizującymi doświadczenie, „to nie ma znaczenia, czy ich przesłanki są realistyczne”. Dalej Wendt argumentuje: ,[p]roblem polega na tym, że ponieważ proces może być modelowany, 'jak gdyby' to działało w pewien sposób, w rzeczywistości wcale nie musi działać w ten sposób" (Wendt, 2008: 65), a w konsekwencji możemy nigdy nie zabrać się do wyjaśniania, jak to naprawdę działa. Stanowisko Wendta faworyzuje tym samym filozofię realizmu naukowego. Dla antyrealisty odpowiedź na pytanie, która teoria powinna zostać przyjęta, zależy od określenia, która teoria jest predyktywnie najlepsza. Antyrealizm 
nie zakłada, że mamy dostęp do „faktu”, czyli do tego, jak świat działa poza naszymi empirycznymi obserwacjami. Czy zatem teoria musi być „realistyczna”? Kenneth Waltz, który z pewnością zajmuje stanowisko antyrealistyczne, w swoich rozważaniach o teorii stwierdza, że wyizolowanie dziedziny, której teoria będzie dotyczyć, jest wstępnym warunkiem jej powstania. „Nie pytamy się wszakże o to, czy wyizolowanie dziedziny jest realistyczne, lecz o to, czy jest użyteczne, przy czym użyteczność osądzamy na podstawie mocy wyjaśniania i przewidywania wykazywanej przez tworzoną teorię" (Waltz, 2010: 16). A. Wendt broni realizmu naukowego, aby zapobiec a priori argumentom blokującym poważne teoretyzowanie w NSM. Jednak jego zabiegi w istocie potwierdzają, że zanim poddamy rozmaite perspektywy testom empirycznym, musimy je odrzucić jako „nierealistyczne”.

Wendt ostrzega również przed drugim niebezpieczeństwem instrumentalizmu: „[e]mpirystyczni przedstawiciele nauk społecznych mogą dojść do wniosku, że instrumentalistyczny zakaz odnosi się do badania społeczeństwa, tak samo jak do przyrody, i wobec tego odrzucić a priori jako 'metafizyczną' każdą teorię, która odwołuje się do czegoś nieobserwowalnego" (Wendt, 2008: 66). Jednak, jak pokazuje przykład $\mathrm{K}$. Waltza, w gruncie rzeczy instrumentaliści nie mają wielkiego problemu z nieobserwowalnymi pojęciami. Uważany za instrumentalistę K. Waltz stwierdza: ,[t]eorie zawierają nie tylko pojęcia opisowe, lecz również teoretyczne. Nie da się ich skonstruować wyłącznie za pomocą indukcji, ponieważ pojęć teoretycznych nie można odkryć - trzeba je wymyślić" (Waltz, 2010: 13). Ostatecznie oba argumenty Wendta przeciwko instrumentalizmowi należą do "słabszych desek w jego teoretycznej platformie" (Chernoff, 2002: 196).

W głównym nurcie TSM, według Steve'a Smitha, dominują epistemologiczne założenia pozytywizmu, przez które rozumie on „wiarę w naturalizm w świecie społecznym (to jest przekonanie, że świat społeczny można badać w ten sam sposób jak świat naturalny); rozdział między faktami i wartościami, to znaczy przekonanie, że 'fakty' są neutralne wobec teorii i że normatywne przekonania nie powinny wpływać na to, co uważamy za fakty lub wiedzę; dążenie do odkrywania wzorców i regularności $\mathrm{w}$ świecie społecznym, które istnieją niezależnie od metod, jakimi posługujemy się w ich odkrywaniu; i w końcu przekonanie, że empiryzm jest arbitrem rozstrzygającym o tym, co jest wiedzą" (Smith, 2000: 383) . $^{8}$.

Głównym przedmiotem krytyki pozytywistycznego nurtu w TSM przez antypozytywistów jest traktowane jako naiwne przekonanie o ,zewnętrznym świecie”, które oddaje pogląd, że wiedza o rzeczywistości jest wyprowadzana bezpośrednio z niezależnego od naszego umysłu „zewnętrznego świata”. Krytycy takiego rozumienia pozytywizmu uważają, że jest on w istocie ,anty-realistyczny”. Teoretycy stosunków międzynarodowych nigdy jednak nie rozpatrywali poważnie takiej możliwości

8 S. Smith zauważa również, analizując „International Studies Quarterly”, czasopismo International Studies Association, że większość autorów publikowanych w nim artykułów nie zajmuje explicite żadnej pozycji teoretycznej. Przyjmowane założenia teoretyczne są obecne implicite w wyborach metodologicznych (zazwyczaj ilościowych) i epistemologicznych (zazwyczaj bliskich empiryzmowi). W ten sposób, zdaniem S. Smitha, większość literatury amerykańskiej nie jest explicite racjonalistyczna, ale jest taka implicite. Ontologicznie teksty te należą do przestrzeni definiowanej przez racjonalizm; epistemologicznie są empirystyczne, a metodologicznie są pozytywistyczne. 
(George, 1994: 53). Na przykład, wielu antypozytywistów w TSM umieszcza stanowisko teoretyczne Kennetha Waltza poza „granicą pozytywności”. Tymczasem Waltz określając swój sposób myślenia mówi wprost: „nie pisałem jako pozytywista lub empirysta" (Pond, Waltz, 1994: 198; Wæver, 2009: 201-222). W pracy Theory of International Politics Waltz stwierdza: „[t]o, co myślimy na temat rzeczywistości, jest złożoną koncepcją, konstruowaną i rekonstruowaną przez wieki. Rzeczywistość wyłania się z wyboru i organizacji materiału, którego jest nieskończenie wiele. Jak zdecydować, co należy wybrać, i jak to zorganizować?" (Waltz, 2010: 12).

\section{Konstruktywizm spoleczny (antypozytywizm)}

Za prekursora konstruktywizmu społecznego uznaje się często fizyka Ludwiga Flecka. W sformułowanej w 1935 r. socjologicznej tezie dotyczącej genezy wiedzy naukowej Fleck stwierdzał, że fakty nie są odkrywane przez indywidualnych badaczy, ale tworzone w drodze kolektywnego postępowania badawczego (Liebrucks, 2001: 366). W 1966 r. Peter Berger i Thomas Luckmann opublikowali klasyczną rozprawę The Social Construction of Reality, w której głosili, że rzeczywistość jest tworzona w społecznej interakcji, przy czym przez „rzeczywistość” rozumieli oni nasze przekonania o świecie, a nie świat istniejący niezależnie od nich. Nasza koncepcja rzeczywistości nie jest samą rzeczywistością. Uważali zatem, że nasze przekonania o rzeczywistości są konstruowane w społecznej interakcji; społeczne instytucje i osoby są konstruowane w społecznej interakcji; przekonania o rzeczywistości konstruowane w społecznej interakcji odgrywają znaczącą rolę w (re)konstrukcji instytucji i osób (teza o refleksyw$n o s ́ c i$ ). Nie tylko zatem procesy społeczne są konstytutywne dla formowania naszych przekonań, ale i nasze przekonania w dialektyczny sposób, przez nasze dyskursy i działania, wpływają na procesy społeczne.

Pomimo nieco różniących się orientacji metateoretycznych, które można identyfikować jako konstruktywistyczne, kluczowa zasada rządząca konstruktywistyczną filozofią nauki wyraża się w tezie o tworzeniu obiektów społecznych i naszej wiedzy o nich. Jako filozofia nauki konstruktywizm społeczny podkreśla intersubiektywny aspekt świata społecznego tworzonego przez rozmaite intersubiektywne systemy reguł i przekonań. Przekonania te nie tylko kierują naszym rozumieniem i działaniem w świecie społecznym, ale także leżą u podstaw naszej wiedzy tworzonej w społecznie konstruowanym środowisku. Epistemologiczne zasady konstruktywizmu nakazują nam przywiązywać szczególną wagę do „rozumienia” reguł i norm leżących u podstaw działania społecznych podmiotów sprawczych i ich wpływu na analizę „społecznych prawd”. To język nadaje znaczenie światu, a nie odwrotnie. „Przedmioty” naukowego badania nie są niezależne od społecznego kontekstu i dyskursu, które je definiują. Oznacza to, że ontologia (to, co jest) jest uwikłana w epistemologię (jak to wiemy) w stopniu czyniącym taką dystynkcję pozbawioną znaczenia. Nacisk na rolę języka, znaczenia i społecznego kontekstu prowadzi konstruktywistów społecznych do rozumienia „prawdy naukowej” jako funkcji tego, co jest powszechnie akceptowane przez naukowców jako prawda, to znaczy jest rezultatem społecznie wytwarzanego konsensu. Konsens ten jest funkcją społecznego kontekstu („dominującego paradygmatu” 
w terminologii T. Kuhna), w ramach którego naukowcy definiują swoje cele naukowe, metody i standardy potwierdzania (Monteiro, Ruby, 2009: 28-29).

Konstruktywistów społecznych można podzielić na ,umiarkowanych” i „,radykalnych". Umiarkowani konstruktywiści, zarówno w filozofii nauki, jak i w TSM, dowodzą, że dzięki zrozumieniu społecznie konstruowanego kontekstu działania możemy osiagnąć lepsze zrozumienie świata społecznego. Radykalni konstruktywiści dowodza, że nie można mówić o żadnej obiektywnej społecznej rzeczywistości w społecznie konstruowanym świecie (Kurki, 2009: 446-447). Nauka raczej wymyśla prawdy niż je odkrywa. Tym samym radykalny konstruktywizm społeczny podważa uprzywilejowany status nadawany wiedzy naukowej i zajmuje stanowisko antypozytywistyczne. Nauka jest przedsięwzięciem kierowanym partykularnymi celami różnych grup naukowców, związanym $\mathrm{z}$ interesami zaangażowanych $\mathrm{w}$ nie aktorów społecznych i rozkładem władzy między nimi.

W NSM panuje dość powszechna zgoda, że w latach dziewięćdziesiątych XX w. pojawił się nowy „konstruktywistyczny” sposób teoretyzowania i analizy stosunków międzynarodowych. Odrzucając racjonalizm neorealizmu i neoliberalizmu oraz realizmu politycznego i neorealizmu, konstruktywiści proponowali socjologiczną (społeczną) perspektywę rozumienia stosunków międzynarodowych podkreślającą znaczenie struktur zarówno normatywnych (ideacyjnych), jak i materialnych; rolę tożsamości w określaniu interesów i działania oraz wzajemne konstytuowanie się podmiotów sprawczych (agentów) i struktur (Price, Reus-Smit, 1998: 259). Czołowi konstruktywiści explicite uważali się za teoretyków krytycznych i wyprowadzali swoje intelektualne korzenie z trzeciej debaty w NSM oraz nawiązywali do kanonu myśli przedstawicieli krytycznej teorii społecznej, takich jak Anthony Giddens, Jürgen Habermas i Michel Foucault oraz ich prekursorów (Karol Marks, Fryderyk Nietzsche). Uznawali konstruktywizm za przynależny do szerokiej „rodziny” teorii krytycznych, obok postmodernizmu, neomarksizmu, feminizmu. Ta samoidentyfikacja wzbudzała jednak sprzeciw zwolenników teorii krytycznej, którzy uważali, że konstruktywizm jest rodzajem zamaskowanego racjonalizmu i pozytywizmu (Campbell, 1996: 7-32; Linklater, 1996: 279-300).

Niektórzy zwolennicy teorii konstruktywistycznej w NSM sytuują ją w „połowie drogi" między racjonalizmem a reflektywizmem. Jeden z nich, Alexander Wendt, którego celem było zbudowanie „mostu”, pośredniej drogi (via media) między tymi stanowiskami, w Spolecznej teorii stosunków międzynarodowych broni „umiarkowanej”, ,słabej” wersji konstruktywizmu przed atakami z dwóch stron. Krytykuje on tych autorów głównego nurtu, którzy odrzucają społeczny konstuktywizm jako równoznaczny z postmodernizmem, a jednocześnie przeciwstawia się ,,bardziej radykalnym” konstruktywistom. „Wersja konstruktywizmu, której bronię, ma charakter umiarkowany i opiera się zwłaszcza na symbolicznym interakcjonizmie i socjologii strukturacjonistycznej. Jako taka przyznaje w niektórych istotnych kwestiach rację perspektywie materialistycznej oraz indywidualistycznej. Popiera też naukowe podejście do badań społecznych. Może być z tych powodów odrzucana przez bardziej radykalnych konstruktywistów, gdyż nie idzie dość daleko; jest to rzeczywiście słaby konstruktywizm. Idzie jednak znacznie dalej niż obecnie większość uczonych z głównego nurtu badań stosunków międzynarodowych, którzy czasem odrzucają jako 'postmodernizm' jakąkol- 
wiek wzmiankę o społecznej konstrukcji. Mam nadzieję znaleźć między tymi ekstremami drogę pośrednią, opartą na zasadach filozoficznych" (Wendt, 2008: 11-12). W swojej wersji umiarkowanego konstruktywizmu A. Wendt dowodzi, że konstruktywiści są modernistami (pozytywistami) w pełni popierającymi naukowy projekt falsyfikacji teorii za pomocą danych (Wendt, 1995: 75).

Radykalni konstruktywiści nie akceptuja jednak propozycji A. Wendta. Klasyfikując konstruktywizm John Ruggie wymienia trzy jego warianty: neoklasyczny, oparty na intersubiektywnych znaczeniach i nawiązujący do socjologii Emila Durkheima i Maxa Webera; postmodernistyczny, oparty na epistemologicznym zerwaniu z modernizmem i nawiązujący do prac Fryderyka Nietzschego, Michela Foucaulta i Jacques'a Derridy; oraz naturalistyczny, oparty na filozofii naukowego realizmu zawartej w pracach Roya Bhaskara (Ruggie, 1998: 35-36).

\section{Naukowy realizm (postpozytywizm)}

Wszystkie wersje naukowego realizmu podzielają podstawową tezę głoszącą, że nauka jest zdolna odzwierciedlić działanie świata. W odróżnieniu zarówno od instrumentalizmu, jak i społecznego konstruktywizmu, naukowy realizm nadaje priorytet ontologii przed epistemologia. Filozofia naukowego realizmu jest „realistyczna” w dwóch podstawowych znaczeniach: ontologicznym - zakłada, że świat istnieje niezależnie od naszego umysłu, nawet jeśli rzeczywistość nie jest identyczna z tymi cechami, które wykrywamy za pośrednictwem naszych zmysłów, ponieważ ma ona głęboką strukturę przyczyn, sił i tendencji; epistemologicznym - zakłada, że wiedza i praktyka naukowa rzeczywiście istniejąaka odrębne rodzaje wiedzy i aktywności.

Filozofia naukowego realizmu znajduje wyraz w różnych formach. Jedno z najbardziej znanych stanowisk przedstawił Hilary Putnam na przełomie lat sześćdziesiątych i siedmdziesiątych XX w. Według Putnama realista uważa, że wnioski określonej teorii lub dyskursu są prawdziwe lub fałszywe oraz tym, co czyni je prawdziwymi lub fałszywymi jest coś ,zewnętrznego”, ale nie nasze dane, aktualne lub potencjalne, ani struktura naszego umysłu lub języka. Putnam jest autorem argumentu na rzecz naukowego realizmu, który w literaturze określa się często jako „ostateczny” lub argument „z cudu”: gdyby nie można było przyjąć, że teorie naukowe prawdziwie opisują rzeczywistość, a pojęcia naukowe mają swoje odniesienia przedmiotowe, to, co robi nauka byłoby cudem. Nauka odnosi sukces, ponieważ prowadzi do zgodności między naszą teorią a głęboką strukturą istniejącego świata. ,Jeśli dojrzałe teorie nie byłyby zgodne z grubsza z tą struktura, to byłoby 'cudem', że tak dobrze się sprawdzają. To jest wnioskowanie do najlepszego wyjaśnienia: przyjmowanie, że to jest cud, nie jest wyjaśnieniem i nie widząc lepszego wyjaśnienia, realiści uważają, że najlepszym wyjaśnieniem sukcesu nauki jest to, że zbliżyliśmy się bardziej do struktury rzeczywistości” (Wendt, 2008: 68). Łatwo zauważyć, że wersja naukowego realizmu Wendta jest bardzo zbliżona do koncepcji Putnama, który jednak w końcu lat siedemdziesiatych odrzucił naukowy realizm. Inni filozofowie nauki, na przykład Roy Bhaskar i Bas van Fraassen, opowiadają się za takim lub innym wariantem naukowego realizmu. Najkrócej mówiąc, wśród filozofów nauki trwa na ten temat intensywna debata (Chernoff, 2002: 193). 
W TSM Alexander Wendt opierając się na neorealizmie Kennetha Waltza i korzystając z szerokiej literatury politologicznej, socjologicznej i filozoficznej zajął stanowisko ideacyjne, wsparte przez idealistyczną i holistyczną ontologię. Równocześnie uznał on także zasady naukowości wyznaczane przez szeroko rozumiany pozytywizm. System państw jest dla niego realnie istniejącą strukturą, której naturę można uchwycić metodami naukowymi. Akceptacja tego stanowiska wymaga ,przyjęcia 'naukowego realizmu' [...], to jest filozofii nauki, która zakłada, że świat istnieje niezależnie od istot ludzkich, a dojrzałe teorie naukowe zwykle odnoszą się do tego świata i czynią tak nawet wówczas, gdy przedmioty, którymi zajmuje się nauka, są nieobserwowalne. Teoria odzwierciedla rzeczywistość, innej możliwości nie ma; jak lubią mówić realiści, chcą 'ontologię postawić przed epistemologią' "(Wendt, 2008: 53). Naukowi realiści uznają zatem, że celem nauki jest poszukiwanie prawdy zarówno w rzeczywistości poddającej się obserwacji, jak i w rzeczywistości nieobserwowalnej oraz że nauka osiąga postęp w realizacji tego celu, a teorie naukowe oferują najlepsze lub jedyne możliwe wyjaśnienie określonych zjawisk (Lyons, 2009: 66).

Według A. Wendta większość prac poświęconych TSM - zarówno z głównego, jak i krytycznego nurtu - wydaje się opierać na przyjętym z góry założeniu, że tak właśnie jest. Oznacza to, że ich autorzy są co najmniej „,cichymi realistami”; jednak gdy przedstawiają oni swoje poglądy filozoficzne, zajmują często stanowisko antyrealistyczne. Odniesienia do realistycznej filozofii nauki są w NSM niezwykle rzadkie. Ten brak zainteresowania jest według Wendta zaskakujący, skoro wśród współczesnych filozofów nauki realizm stał się przeważającym stanowiskiem ontologicznym (Wendt, 2008: 53). Jego przekonanie wspiera Stephen Krasner podkreślając, że rozważania Wendta dotyczące naukowego realizmu powinny być obowiązkową lekturą każdego badacza stosunków międzynarodowych (Krasner, 2000: 131).

A. Wendt broni trzech zasad naukowego realizmu głoszących, że świat istnieje niezależnie od umysłu i języka indywidualnych obserwatorów, a dojrzałe teorie naukowe zwykle odnoszą się do tego świata, nawet wtedy gdy nie jest on bezpośrednio obserwowalny. Ponieważ naukowy realizm jest filozofią nauki, a nie teorią społeczeństwa, nie mówi nic o jego naturze ani strukturze. Naukowy realizm umożliwia traktowanie systemu państw jako realnego i poznawalnego, chociaż nie mówi, że on istnieje, z czego się składa i jak się zachowuje. To jest zadanie badacza stosunków międzynarodowych, a nie filozofa nauki (Wendt, 2008: 57).

Niektórzy teoretycy stosunków międzynarodowych, na przykład Heikki Patomäki i Colin Wight, dowodzą jednak, że zajęcie pośredniego stanowiska w debacie między pozytywizmem a antypozytywizmem nie rozwiązuje problemu błędnego samorozumienia przez TSM swoich fundamentów. W tym celu, ich zdaniem, należy odwołać się raczej do filozofii krytycznego realizmu (Patomäki, Wight, 2000: 213; Patomäki, 2002: 89-111). Ostatecznie więc przyjęcie teorii konstruktywistycznej w NSM, szczególnie $\mathrm{w}$ formie via media przedstawionej przez Alexandra Wendta, również nie znosi fundacyjnego sporu między pozytywizmem a antypozytywizmem.

W latach osiemdziesiątych XX w. w NSM główne nadzieje teoretyczne lokowano w próbie syntezy między neoliberalizmem a neorealizmem (tzw. debata neo-neo). Wskazywano również, że marksizm utracił pozycję ,trzeciej” teorii stosunków międzynarodowych. Jednak podstawowe wyzwanie dla tej wizji układu sił w teoretyzowaniu 
o stosunkach międzynarodowych płynęło wtedy ze strony „epistemologicznych radykałów” („wszelkiego rodzaju antypozytywistów”). Jeśli antypozytywiści byli zbyt radykalni, przekraczali ,granicę negatywności” i znajdowali się po stronie dekonstrukcyjnej. Jeśli zwolennicy neo-neo byli zbyt pozytywistyczni, przekraczali ,granicę pozytywności”. W kolejnej dekadzie rozwiązania pozwalającego uniknąc tych pułapek próbował dostarczyć umiarkowany konstruktywizm. Patomäki i Wight uznają jednak tę próbę za niesatysfakcjonującą. Sami proponują usunięcie obu pułapek przez odwrócenie zachodniego dogmatu filozoficznego polegającego na uprzywilejowaniu epistemologii nad ontologią i skoncentrowanie się na tej drugiej. Mają na względzie ontologię filozoficzną, która stanowi fundament rozwoju każdej ontologii naukowej lub społecznej. Ontologia, do której się odwołuja jest realizm krytyczny. Sięgają w tym celu do filozofii nauki, na gruncie której binarna opozycja między pozytywizmem a antypozytywizmem nie jest tak oczywista, jak to wynika z jej rozumienia przez teoretyków NSM. Filozof nauki Larry Laudan wskazuje na założenia wspólne dla obu filozofii. Na przykład, szczególna rola języka w teorii antypozytywistów ma swój odpowiednik w bardziej radykalnej próbie zredukowania filozofii i nauki do języka na gruncie pozytywizmu logicznego (Patomäki, Wight, 2000: 216). Atak antypozytywistów na kartezjański podmiot był równie gwałtowny jak pozytywistów, którzy dążyli w ten sposób do usunięcia subiektywności ze swojej epistemologii. Patomäki i Wight analizują zajmowanie stanowisk poza ,granicą negatywności” i poza ,granicą pozytywności" z pozycji realizmu krytycznego. W pierwszym przypadku, w kategoriach epistemologii oznacza to zaprzeczenie istnienia obiektów niezależnie od dyskursów, które je tworzą. Jeśli dyskursy tworzą obiekty, do których się odnoszą, to sam dyskurs nigdy nie może być błędny w kwestii istnienia tych obiektów, ponieważ sam je powołuje do życia. Alternatywny dyskurs nie może w związku z tym krytykować innego dyskursu, ponieważ obiekty tego dyskursu istnieją, jeśli dyskurs mówi, że one istnieją. Jakakolwiek zewnętrzna krytyka sądów formułowanych na gruncie określonego dyskursu wydaje się zatem niemożliwa. Ujmując natomiast rzecz z punktu widzenia ontologicznego: jeśli dyskursy konstruują swoje obiekty, co konstruuje same dyskursy? Metodologicznie powoduje to, że poza „granicą negatywności” argumenty są nieustannie tworzone i oceniane.

Poza „granicą pozytywności” sytuacja wygląda nieznacznie inaczej. Epistemologia i ontologia zostają powiązane, to, co jest znane, może być doświadczane i/lub obserwowane. Nieobserwowalne teoretyczne pojęcia są traktowane instrumentalnie: są one użytecznymi „fikcjami” i w związku z tym nie mogą być traktowane jako realnie istniejące. Tak rozumiany empiryzm nie pozwala jednak na uwolnienie się od subiektywności. Świat „zewnętrzny” jest nierozerwalnie związany ze światem „wewnętrznym” [ibidem: 216).

Dla realisty lepszym rozwiązaniem jest więc explicite akceptacja istnienia rzeczywistości. Głęboki realizm stanowi zatem wyzwanie dla obu stanowisk (pozytywizmu i antypozytywizmu). Świat jest realny, a wszystkie filozofie, kognitywne dyskursy i praktyczna aktywność zakładają realizm. Celem nauki jest poznanie, czy rzeczywiście świat jest taki, jak ona go opisuje, bez pewności, że wyniki nie zostaną podważone. W konsekwencji przyjęcie stanowiska realistycznego jest traktowane jako warunek wyjścia poza obie granice. Problem nie polega na byciu realista, ale na rozstrzygnięciu, 
jakim się jest realistą. Ci, którzy sytuują się poza „granicą pozytywności” są empirycznymi realistami; ci, którzy mieszczą się poza ,granicą negatywności” są realistami lingwistycznymi. Krytyczny realizm różni się od empirycznego i lingwistycznego na dwa sposoby. Po pierwsze, realiści krytyczni uznają że świat składa się nie tylko z wydarzeń, doświadczeń, impresji i dyskursów, ale także ze struktur, sił i tendencji, które istnieją niezależnie od tego, czy je wykrywamy i w jaki sposób to robimy (przez doświadczenie i/lub dyskurs). Realizm krytyczny łączy zatem różne poziomy rzeczywistości w jedną rzeczywistość. Po drugie, różne poziomy rzeczywistości nie muszą znajdować się w tej samej fazie. Podstawowy poziom rzeczywistości może obejmować pewną potencjalność (siły i tendencje), która nie zawsze się manifestuje lub realizuje $\mathrm{w}$ doświadczeniu. $\mathrm{Z}$ tego punktu widzenia świat zawsze zawiera więcej niż aktualny przebieg wydarzeń i doświadczeń lub dyskursów o nim. Celem poznania naukowego jest przede wszystkim rozpoznanie struktur, sił i tendencji, które strukturyzują przebieg wydarzeń. Różne teorie mogą zatem interpretować ten sam świat w radykalnie odmienny sposób. Jednak ponieważ dążymy do zdobycia wiedzy o rzeczywistości istniejącej niezależnie, wiedza ta nie może być całkowicie arbitralna i niektóre sądy o naturze poznawanej rzeczywistości dostarczają lepszych wyjaśnień niż inne (ibidem: 224).

Jednym z celów uzasadniających przyjęcie przez Wendta filozofii naukowego realizmu w teoretyzowaniu o stosunkach międzynarodowych była również próba przeniesienia debaty z epistemologii do ontologii. Miało to umożliwić znalezienie wspólnej podstawy dla różnych teoretycznych perspektyw. Jednak rozwiązanie, które Wendt proponuje, samo zależy wprost od przyjęcia naukowego realizmu jako pośredniej drogi do powiązania realistycznej ontologii z pozytywistyczną epistemologią.

Tabela 2 zawiera podsumowanie stanowisk trzech dominujących filozofii nauki w odniesieniu do podstawowych kwestii fundacyjnych.

Tabela 2

Główne stanowiska fundacyjne w filozofii nauki

\begin{tabular}{|l|l|l|l||}
\hline \multicolumn{1}{|c|}{ Fundamentuum } & \multicolumn{1}{|c|}{ Instrumentalizm } & \multicolumn{1}{c|}{$\begin{array}{c}\text { Konstruktywizm } \\
\text { społeczny }\end{array}$} & \multicolumn{1}{|c||}{ Naukowy realizm } \\
\hline Ontologia & Fenomenalizm & Konstytucjonizm & Realizm \\
\hline Epistemologia & Empiryzm & Społeczna & Reprezentacjonizm \\
\hline $\begin{array}{l}\text { Ontologia vs epistemolo- } \\
\text { gia }\end{array}$ & $\begin{array}{l}\text { Epistemologia określa on- } \\
\text { tologię }\end{array}$ & $\begin{array}{l}\text { Odrzucenie tego rozróż- } \\
\text { nienia }\end{array}$ & $\begin{array}{l}\text { Ontologia określa episte- } \\
\text { mologię }\end{array}$ \\
\hline Kryterium prawdy & Obserwacja & Konwencja & $\begin{array}{l}\text { Obserwacja i inferencja do } \\
\text { najlepszego wyjaśnienia }\end{array}$ \\
\hline Rozumienie prawdy & Empiryczna adekwatnośćc & Akceptowane przekonanie & $\begin{array}{l}\text { Korespondencja z rzeczy- } \\
\text { wistością }\end{array}$ \\
\hline Cel nauki & $\begin{array}{l}\text { Użyteczność i niezawod- } \\
\text { ność }\end{array}$ & Cele partykularne & Poznanie rzeczywistości \\
\hline $\begin{array}{l}\text { Stosunek do naukowego } \\
\text { postępu }\end{array}$ & Nauka jest progresywna & $\begin{array}{l}\text { Nauka nie jest progresyw- } \\
\text { na }\end{array}$ & Nauka jest progresywna \\
\hline Stanowisko filozoficzne & Pozytywistyczne & Antypozytywistyczne & Postpozytywistyczne \\
\hline \hline
\end{tabular}

Źródło: Oprac. na podstawie: N. P. Monteiro, K. G. Ruby (2009), IR and the false promise of philosophical foundations, „International Theory”, Vol. 1, No. 1, s. 33. 


\section{TEORIA STOSUNKÓW MIĘDZYNARODOWYCH A FILOZOFIA NAUKI. CO ROBIĆ?}

Jeśli filozofowie nauki nie potrafią uzgodnić ontologicznych, epistemologicznych i metodologicznych fundamentów nauk, pomimo że stanowi to przedmiot ich podstawowej aktywności, nie może dziwić, że nie potrafią tego osiagnąć również zajmujący się TSM. W konsekwencji fundacyjna debata w NSM, według Monteiro i Ruby'ego, wręcz utrudnia rozwój dyscypliny. Badacze stosunków międzynarodowych nieustannie poszukują niewzruszonych filozoficznych podstaw dla swojej dyscypliny, zdolnych rozstrzygnąć w sposób ostateczny jej przedmiot, zakres, cel, kryteria, standardy i metody. Jednak wybór którejkolwiek z propozycji oferowanych przez filozofię nauki nieuchronnie wytycza odmienną drogę gwarantowania naukowego bezpieczeństwa. Dyskusje na ten temat przyjmują często bardzo ostre formy. Ich poważniejszym skutkiem jest rozbicie dyscypliny w kwestiach metateoretycznych i metodologicznych. Zasadniczy podział między pozytywistami a antypozytywistami utrudnia dialog między nimi w żywotnych sprawach dotyczących stosunków międzynarodowych. Najkrócej mówiąc, sięganie po argumenty do filozofii nauki w celu rozwiązania sporów w istocie je pogłębia i utrudnia wewnątrzdyscyplinarne porozumienie (Monteiro, Ruby, 2009: 24).

Co więcej, coraz trudniej ignorować fundacyjne problemy, jeśli teoretycy NSM dzielą różne rodzaje teoretyzowania na „akceptowalne” i ,nieakceptowalne” (Chernoff, 2002: 200-201). Fred Chernoff rozwiązania tej dychotomii upatruje w oddzieleniu postawy „epistemologicznego fundacjonalizmu” od „teorii fundacyjnej”; pierwsza polega na budowaniu korpusu wiedzy z zestawu niekwestionowanych „fundacyjnych” przesłanek, druga proponuje zestaw filozoficznych i metodologicznych zasad, które pomagają uporać się z dylematami stawianymi przez (społeczną) teorię naukową i praktykę. Można oferować epistemologiczne fundamenty bez epistemologicznego fundacjonalizmu. Prawie wszyscy, którzy odrzucają ,epistemologiczny fundacjonalizm" są zgodni, że akceptacja pewnych przesłanek jest logicznym skutkiem akceptacji innych. Epistemologiczne fundamenty lub metateoria mogą zatem być użyteczne również dla tych, którzy są w filozoficznym znaczeniu ,epistemologicznymi antyfundacjonalistami" (ibidem: 201).

W filozofii i socjologii nauki debata między realistami a antyrealistami (konstruktywizm społeczny jest zwykle traktowany jako wariant antyrealizmu) wyczerpała się na początku ostatniej dekady XX w., przynajmniej jako kontrowersja, którą można by rozwiązać w pouczający sposób. Wielu socjologów wiedzy naukowej (historycy kultury, antropolodzy i teoretycy nauki spod znaku feminizmu) podjęło postkonstruktywistyczne badania nauki (Rouse, 2002: 62). Joseph Rouse proponuje uznać konstruktywizm społeczny i realizm za stanowiska, które nie są ani żywe, ani martwe, ale są raczej filozoficznymi „wampirami”, które ciągle nawiedzają nasze pojęcia i interpretacje natury, kultury i nauki. Pojęcia natury, kultury i natury podmiotu sprawczego, które kierują debatami, nadal funkcjonuja, nawet jeśli zajmowane w nich explicite stanowiska i argumenty stały się zbyteczne. W posługiwaniu się nimi przeszkadzają symboliczne granice między naturą a kultura, ludzkim a nieludzkim, rozumnym a nierozumnym, których przekraczanie zbyt często wydaje się zarazem nieuniknione i niepożądane (ibi- 
dem: 63). Bardziej radykalne postkonstruktywistyczne tezy formułowane w ostatnich badaniach nad nauką kwestionują traktowanie natury i społeczeństwa (kultury) jako zamkniętych w sobie komponentów świata, które wchodzą w interakcje za pośrednictwem ludzkich artefaktów, ciał i języka naukowego (lub pojęć). Naukowe rozumienie nie dokonuje się „wewnątrz” umysłów lub kultur, ale jest wcielone w zjawiska zachodzące w świecie, umiejętności, narzędzia, instytucje i dyskursy, które przecinają tradycyjnie wyznaczane granice między naturalnymi obiektami a społecznymi lub kulturowymi znaczeniami. To, co nauka odkrywa, jest rodzajem bliskości (intimacy), integralności (integralness) materialnej natury i ludzkiego życia społecznego, natury i społeczeństwa lub kultury (ibidem: 69).

Sedno leży zatem, jak się wydaje nie w filozofii, ale w szczególnych filozoficznych założeniach, które kierują debatami. Spójrzmy na problemy wynikające z potrzeby integracji ekologicznej historii ludzkich kultur (Crosby, 1999; Diamond, 2000, 2007) z historiami bardziej tradycyjnymi. Wiele zjawisk - na przykład, powstanie miast, ich przekształcanie się w imperia, europejska kolonizacja - tradycyjnie przedstawiano jako elementy historii społecznej, kulturowej lub politycznej. Historycy ze szkoły ekologicznej proponują interpretować je jako zjawiska biologiczne, które można lepiej wyjaśnić odkrywając symbiotyczne związki między ludzkimi społecznościami a mikrobami, roślinami, zwierzętami. Wyzwaniem jest traktowanie historii ekologicznych i kulturowo-politycznych nie jako rywalizujących narracji, ale jako nierozłącznych aspektów każdego adekwatnego historycznego rozumienia. Znaczący wkład w odsłanianie tego rodzaju związków mogą wnieść postkonstruktywistyczne badania nad nauką. Być może tylko tego możemy się nauczyć z niekończących się debat.

Co robić? Oczywiście, można przedstawić tyle propozycji rozwiązań, ile jest fundacyjnych sporów. Tu ograniczymy się do naszkicowania dwóch, które są próbą ominięcia tego rodzaju sporów i jednego rozwiązania (spośród wielu) zaczerpniętego $\mathrm{z}$ socjologii.

\section{PROPOZYCJA „FUNDACYJNEJ ROZWAGI”}

Impas, w jakim znalazła się debata wokół fundamentów NSM, skłonił Nuna P. Monteiro i Kevina G. Ruby'ego do wniosku, że dyscyplina może funkcjonować bez owych fundamentów. Podstawowy argument na rzecz takiej tezy wynika z podziałów w filozofii nauki - dopóki one istnieją, dopóty poszukiwanie fundamentów dla NSM będzie raczej wzmacniać aniżeli osłabiać ujawnione już różnice.

Proponowaną przez Monteiro i Ruby'ego alternatywę można sprowadzić do rozważnej ,postawy ku” fundamentom rozumianym jako swoista całość; trzeba podkreślić, że „postawę” odróżniają oni od „stanowiska”. Nie należy zatem, uznając argumenty formułowane przez filozofię nauki, ,zmuszać” badaczy stosunków międzynarodowych do przedkładania jednego stanowiska fundacyjnego nad inne. Argument ten jest oparty na dwóch przesłankach. Po pierwsze, każda filozofia nauki wymaga co najmniej jednego ,aktu wiary” jako uzasadnienia swojego roszczenia do prowomocnego wyjaśnienia. Powoduje to, że każda z nich może być celem wyzwania opartego na innym filozoficznym założeniu i tym samym nie może zapewnić NSM bezpiecznych fundamentów. Po 
drugie, debata o ,nauce” sugeruje, że żadna z trzech głównych filozofii nauki nie wyklucza pluralizmu podejść. Rozwój NSM jest przecież dziełem badaczy reprezentujących rozmaite perspektywy metateoretyczne. Konieczność wyboru jednej z tych perspektyw ogranicza możliwości rozpoznania stosunków międzynarodowych (Monteiro, Ruby, 2009: 35-36).

Swoje stanowisko Monteiro i Ruby określają jako „postfundacyjne”, a nie ,antyfundacyjne". Indywidualny badacz jedynie zdobywając konkretną wiedzę może dokonać świadomego wyboru; stanowi to kluczowy element stanowiska postfundacyjnego, odróżniający je od ,prefundacyjnej ignorancji i od dogmatycznego antyfundacjonizmu"9. Ponadto autorzy podkreślają, że postawa ,fundacyjnej rozwagi” wobec fundacyjnych argumentów oznacza również świadomość, że naukowe standardy nie ,płyną naturalnie" z filozofii nauki. NSM wypracowała własne (wewnętrzne) standardy i funkcjonowanie badacza w dyscyplinie nie wydaje się uzależnione wyłącznie od właściwego zrozumienia przezeń lub zajęcia określonego stanowiska postulowanego przez filozofię nauki.

\section{RADY KENNETHA N. WALTZA}

Dyskusje o Theory of International Politics Kennetha N. Waltza przybierały różne formy, zależne od specyficznych aspektów lub linii podziału w debacie o TSM między liberalizmem a realizmem. Z czasem debata ta nabierała coraz bardziej ,,wewnątrzrealistycznego" charakteru (realizm ofensywny versus defensywny; realizm neoklasyczny versus postklasyczny). Debaty o charakterze metateoretycznym dotyczące teorii Waltza skupiały się przede wszystkim na teorii społecznej. Problemy takie jak stosunek między agentem a strukturą, sposób badania społeczeństwa, atomizm/holizm, materializm/idealizm, natura porządku społecznego, uzyskały najbardziej dojrzały wyraz w dyskusji z Waltzem podjętej przez A. Wendta.

Jak zauważa Ole Wæver, w owych debatach filozofia nauki była z reguły ignorowana, z wyjątkiem dyskusji wokół programu badań naukowych Imre Lakatosa. Niemniej jednak w kategoriach ogólnej filozofii nauki stanowisko teoretyczne Waltza było określane w rozmaity sposób, jako pozytywistyczne, instrumentalne, popperowskie, pragmatyczne i naukowo realistyczne. Według Wævera stanowisko teoretyczne Waltza najlepiej współbrzmi z realizmem naukowym, ale żadna z dominujących filozofii nauki nie opisuje właściwie jego metateoretycznych rozstrzygnięć. Waltz wprawdzie

9 Zachęcam do lektury artykułu Monteiro i Ruby’ego w celu zapoznania się ze szczegółami ich propozycji. Warto dodać, że zainspirował on wydawców International Theory do zorganizowania sympozjum pt. Who needs Philosopy of Science anyway? Wystapienia uczestników sympozjum zostały opublikowane w formie artykułów w czasopiśmie „International Theory” 2009, Vol. 1, No. 3. Zob. w szczególności: M. Kurki, The politics of the philosophy of science, s. 440-454; P. T. Jackson, A faulty solution to a False (ly characterized) problem: a comment on Monteiro and Ruby, s. 455-465; F. Chernoff, Defending foundations for International Relations theory, s. 466-477; R. Mercado, Keep muddling through, s. 478-487; J. Bohman, What is to be done? The science question in International Relations, s. 488-498; N. P. Monteiro, K. G. Ruby, The promise of fundational prudence: a response to our critics, s. 499-512. 
podkreślał kluczowe znaczenie filozofii nauki dla jego Theory of International Politics, lecz nie traktował jej jako guru lub kościoła, do którego wstapił. Raczej pobierał lekcje u różnych badaczy, często postrzeganych jako należący do odmiennych filozoficznych obozów. Nie próbował też odpowiedzieć na ostateczne i uniwersalne pytania stawiane $\mathrm{w}$ filozofii nauki i dedukować z nich natury teorii, ale koncentrował się na problemie teorii (Wæver, 2009: 204) ${ }^{10}$.

Akceptując stosunek Waltza wobec metateorii, Ole Wæver zadaje pytanie, czy nadszedł czas, aby sporządzić na nowo mape TSM - wychodząc poza czwartą debatę - z nową „linią frontu” biegnącą między empiryzmem a teorią? Na poziomie analizy, teorii, myślenia i rozumienia Wæver podziela pogląd Waltza, że powinniśmy kłaść szczególny nacisk na konkretne teorie, a nie na mgliste paradygmaty lub szkoły. Więcej bowiem się traci testując niejasne agregaty niż precyzyjne teorie. Jednocześnie uznaje on także socjologiczną rzeczywistość ,szerszych etykietek”, pomimo dominującej obecnie wśród historyków NSM mody polegającej na traktowaniu wielkich debat jako „zwykłych mitów” i opinii oceniających wszelkie -izmy jako szkodliwe. W każdym czasie istnieje pewien sens w budowaniu podstawowych teorii/szkół, frontów i debat, ponieważ pomaga to ustalić, jakie projekty badawcze są bardziej znaczące od innych. TSM mieści się obecnie w obrębie czwartej debaty, która - chociaż już nie tak żywa - ciagle stanowi najważniejszą przestrzeń teoretyzowania. „Spolaryzowana debata racjonalizm/reflektywizm zmutowała $\mathrm{w}$ oś $\mathrm{z}$ coraz większą liczbą badaczy zajmujących miejsce w jej środkowej części, ale ciągle definiujących samych siebie w relacji do tej osi" (ibidem: 217).

O. Wæver wskazuje, że podczas czwartej debaty reflektywiści często „flirtowali” z przedstawicielami klasycznego realizmu (politycznego), próbując wykorzystać ich historyczne podejście jako wsparcie w swojej krytyce neorealistów i racjonalistów. Podkreślanie przez Waltza dystansu między teorią a rzeczywistością oraz przydawanie teorii kluczowego znaczenia rzeczywiście czyni, według Wævera, neorealizm kompatybilny z większością reflektywizmu, jeśli tylko skoncentrujemy się na naturze teorii, a nie ,religijnych podziałach" na pozytywistów i antypozytywistów. Jałowość debaty między pozytywistami a antypozytywistami często podkreślają przedstawiciele realizmu krytycznego, jednak zgłaszane przez nich rozwiązanie rodzi nową metateorię, wywołując reakcje typu „strzeż się guru”, a ponadto prowadzi do filozofii, a nie do TSM (ibidem: 217).

\section{RADY SOCJOLOGII}

Współcześni socjologowie oceniając stan swojej dyscypliny formułują sądy podobne do ferowanych w NSM. Socjologię oglądaną ich oczami charakteryzuje zatem: stan

10 W wywiadzie udzielonym w lutym 2003 r. Waltz mówił: „I’ve spent a lot of time reading the philosophy of science, because it's a very difficult question: What is a theory? What can it do? What can it not do? How do you test its validity or seeming validity? It's a profound and difficult subject in its own right. It also is a field in which there is great literature, and it was a pleasure for me to read in the philosophy of science, and not to have to read a lot more political science”. (Harry Kreisler): „Are you allowed to say that as a former president of the American Political Science Association?" (Kenneth Waltz): „Well, I do!” [Kreisler, 2003]. 
pluralistycznej konfuzji (Donald Levine); degeneracja w formę czystego empiryzmu, bez wartościowych teoretycznych perspektyw kierujących badaniami (Irving Horwitz); fragmentacja teorii, metod i przedmiotu badania (Goran Ahrne); rozdarcie między zobowiązaniami politycznymi a kuszącą pseudofilozofią (Frederik Engelstad); teoretyzowanie zdominowane przez amatorskie dyskusje o problemach ontologiczno-epistemologicznych i próby zredukowania badań złożonych społeczeństw do języka, dyskursu, tekstu, nieświadomości i temu podobnych (Nicos Mouzelis). Współczesna teoria socjologiczna jest oceniana jako namiastka teorii, substytut dla teorii, mieszanina krytyki, filozofii, taksonomii, historii, biografii teoretyków, praktycznie wszystkim tylko nie samą teorią (Barry Barnes) (Brante, 2001: 167).

Socjolog Thomas Brante, który zgłębia problem fragmentacji socjologii, wskazuje na dwa stanowiska w tej kwestii. Dla jednego fragmentacja dyscypliny jest czymś owocnym i interesującym, świadczy o jej żywotności i dynamice; według drugiego powoduje, że jej stan jest opłakany i przygnębiający, wydaje się prowadzić wręcz do rozpadu tożsamości dyscypliny. Brante akceptuje drugi punkt widzenia i postrzega fragmentację socjologii jako problem. Diagnozując ów problem i przedstawiając możliwe sposoby jego rozwiązania stawia dwie tezy: 1) socjologia potrzebuje nowej filozofii nauki, która pomogłaby ją ustabilizować, szczególnie dostarczając socjologom wspólnej platformy i ogólnie podzielanego celu; 2) piętą achillesową współczesnej socjologii jest jej słaby rozwój teoretyczny. W rezultacie potrzebuje ona wzmocnienia przez teorię socjologiczna, a nie tylko teorię zapożyczaną od innych dyscyplin. Tożsamości socjologii nie zapewnia ani jej metodologia, ani przedmiot badań, które dzieli z innymi naukami społecznymi. Socjologia musi zatem dążyć do przekształcenia się w naukę eksplanacyjną, co implikuje konieczność pogłębienia jej własnej teoretycznej wiedzy, to zaś wymaga przede wszystkim ustalenia przedmiotu socjologii. Realizując ten cel Brante najpierw ocenia relacje między socjologią a filozofią nauki, a następnie jako alternatywną dla socjologii filozofię (metateorię) przedstawia ,przyczynowy realizm” będący wariantem krytycznego realizmu (Brante, 2009: 168).

$* * *$

Codzienność współczesnych akademii pokazuje, że niewiele projektów naukowych buduje się, gromadząc poważne dane służące falsyfikacji cudzych lub własnych teorii. Sposobem komunikacji między badaczami jest raczej debata aniżeli dialog. Większe korzyści przynosi dowodzenie przeciw sobie niż uczenie się od siebie. W NSM niewiele dzisiaj wskazuje na możliwość wyeliminowania frustracji wynikającej z istniejących podziałów. Z kolei historia NSM jako dyscypliny nie ujawnia nieodpartych argumentów na rzecz konkretnego uprzywilejowanego sposobu opisu oraz wyjaśniania zjawisk i procesów występujących w sferze stosunków międzynarodowych. Przeciwnie, znaczna część dorobku dyscypliny pokazuje, że przetrwały te tradycje teoretyczne (paradygmaty lub programy badawcze), które potrafiły zaadaptować się do spełniania trzech funkcji: zachowania tego, co wartościowe w naszej puli wiedzy; odrzucenia tego, co nie wydawało się właściwe; i najczęściej odnawiania istniejących tradycji na wyższym poziomie wyrafinowania (Hellmann, 2003: 148). Jak uczy historia NSM, najbardziej produktywny dialog był często rezultatem prac indywidualnych badaczy. 
Odsłaniając konserwatyzm i elitaryzm teorii realizmu politycznego Hansa J. Morgenthaua i realizmu strukturalnego Kennetha N. Waltza, Piki Idh-Shalom przekonuje, że w ocenie teorii stosunków międzynarodowych należy uwzględnić coś więcej niż tylko ich precyzję i związek ze światową polityką. Przede wszystkim trzeba poznać ich moralny fundament i moralne implikacje dla praktyki międzynarodowej. Ów moralny fundament wpływa bowiem nie tylko na stosunki między państwami i społeczeństwami, ale także na to, jak dane społeczeństwo jest rządzone, a jego polityka zagraniczna formowana. Teorie zaś wyrastają nie tylko z analizy „twardych faktów”, ale także z moralnych i ideologicznych przekonań (Idh-Shalom, 2006: 463). Debaty dotyczące odmiennych założeń nie mogą zostać rozstrzygnięte, ponieważ świat teoretyczny jest tak samo podzielony jak świat polityczny. Szerszy konsensus można osiagnąć w kwestiach takich jak dokładność mierzenia, słabości definicyjne, błędy metodologiczne i logiczne. Jednak w pytaniach „wyższego rzędu” chodzi o coś więcej. Rozstrzygnięcia a priori dotyczące natury podmiotu sprawczego i jego stosunku do struktur społecznych, roli idei i czynników materialnych w życiu społecznym nie dają się oddzielić od przekonań ideologicznych na temat społeczeństwa i polityczności. Ponieważ problemów tych nie można rozstrzygnąć ani filozoficznie, ani w życiu politycznym, nieuzasadnione byłoby przewidywanie, że można to uczynić w świecie teorii. W kontekście ideologicznym trzeba także postrzegać paradygmatyczne debaty o stosunkach międzynarodowych, poczynając od Tukidydesa.

Chociaż moje preferencje fundacyjne wiążą się z krytycznym realizmem, być może jedynym zaleceniem $\mathrm{w}$ tym względzie jest zwrot ku normatywnej filozofii nauk społecznych, która poważnie traktuje konstytutywny stosunek między wartościami a faktami. Normatywna filozofia nauk społecznych może połączyć etykę naukowej obiektywności z etyką normatywną i wprowadzić moralne uzasadnianie, argumentację i ocenę w proces eksplanacyjnego teoretyzowania oraz odsłaniać i oceniać normatywne podstawy rozmaitych teorii społecznych (ibidem: 464).

W ostatnich trzech dekadach można było obserwować w NSM istotne zmiany polegające na dezintegracji, formowaniu się, traceniu i zdobywaniu uznania przez różne konkurujące sposoby myślenia. Ortodoksyjny realizm polityczny, który krytykował idealizm jako sposób myślenia w większym stopniu nastawiony na refleksję nad tym, jak być powinno, aniżeli jak jest, stał się przedmiotem ostrej krytyki ze strony zwolenników rewolucji antypozytywistycznej (Lapid, 1989: 235-254). Bycie realistą politycznym nie oznacza przecież, że jest się „realistycznym”. Implikacje głównych nurtów antypozytywizmu (teorii krytycznej, postmodernizmu, teorii feministycznej, konstruktywizmu, socjologii historycznej) polegały nie tyle na zwróceniu uwagi na znaczenie problematyki normatywnej, ale wręcz na postawieniu bardziej radykalnej tezy - że stosunki międzynarodowe jako przedmiot badania w sposób nieunikniony mają charakter normatywny. Teza ta nie była wezwaniem do większego zainteresowania problematyką normatywną, lecz przypominała, że problemy tego rodzaju zawsze stanowiły istotę refleksji nad stosunkami międzynarodowymi, a pozytywistyczna neutralność wobec wartości była projektem normatywnym w stopniu większym niż podejścia marginalizowane i delegitymizowane w imię nauki (Smith, 1992: 489). Rozmaite nurty antypozytywistyczne $\mathrm{w}$ ramach teoretyzowania o stosunkach międzynarodowych w szczególny sposób podniosły problem reifikacji pojęć stosowanych w NSM. 
Choć nie zdołały uzgodnić stanowiska w kwestii rekonstrukcji TSM, przyczyniły się do podważenia dominującej w dyscyplinie epistemologii. Zarzuciły bowiem NSM nie tylko zaślepienie pozytywistyczną epistemologia, ale także dominację epistemologii nad ontologią: jeśli czegoś nie można zmierzyć, to nie istnieje. Logika ta prowadziła do marginalizacji zainteresowań normatywnych. Dopiero gdy empiryczno-ilościowa faza pozytywizmu osiagnęła swój szczyt, ta problematyka powróciła. W Stanach Zjednoczonych, w związku z wojną wietnamska, debata nad problemami normatywnymi sytuowała się ponad rolą teorii i wartości w nauce. Sytuacja radykalnie się zmieniła w latach osiemdziesiątych i dziewięćdziesiatych, prowadząc do daleko większej destabilizacji dyscypliny, aniżeli tylko dystynkcja między teorią normatywną a nienormatywną. $Z$ jednej strony postmodernizm podkopał NSM w takim stopniu, że często wzbudzało to gniew atakowanych. Z drugiej strony NSM długo funkcjonowała na zasadzie ,strażnika bramy”, broniąc się przed radykalnymi interwencjami. Na przykład, przez lata z dyscypliny był wykluczany marksizm, ponieważ uznawano, że nie mówi niczego istotnego o ,realnych” problemach. W latach osiemdziesiątych bariery ochronne zostały ustawione raz jeszcze. W pewnych okolicznościach przyczyny odrzucania konkurencyjnych teorii mają w oczywisty sposób charakter polityczny, mianowicie jeśli kwestionują wartości polityczne wyznawane przez dominujących przedstawicieli dyscypliny. Jednak najczęściej ich uzasadnieniem jest przewaga pozytywistycznej epistemologii.

Jeśli jednak ,chce się ująć spójność jakiejś tradycji badawczej w kategoriach reguł, niezbędne jest wskazanie wspólnej podstawy, na jakiej oparte są badania w danej dziedzinie. W rezultacie poszukiwanie zespołu reguł konstytuujących daną tradycję badań jest źródłem ciągłych i głębokich rozczarowań” (Kuhn, 2001: 88-89). Przedstawiając jeden z aspektów niewspółmierności rywalizujących ze sobą paradygmatów, T. S. Kuhn ukazuje go przez porównanie do sytuacji zwolenników tych paradygmatów, uprawiających swój zawód w różnych światach: ,[u]czeni pracujący w różnych światach, spoglądając $\mathrm{z}$ tego samego punktu w tym samym kierunku, dostrzegają coś innego. I [...] nie znaczy to, że mogą widzieć wszystko, czego dusza zapragnie. Jedni i drudzy patrzą na ten sam świat, który nie uległ przecież zmianie. Ale w pewnych obszarach widzą różne rzeczy pozostające ze sobą w odmiennych stosunkach" (ibidem: 261). Decyzja o wyborze danego paradygmatu opiera się nie tyle na jego dotychczasowych osiągnięciach, ile na zapowiedziach na przyszłość. „Osoba przyjmująca nowy paradygmat we wczesnej fazie jego rozwoju musi często decydować się na to wbrew świadectwom co do jego aktualnej przydatności w rozwiązywaniu zagadnień. To znaczy musi ona wierzyć, iż nowy paradygmat wyjdzie w przyszłości zwycięsko z konfrontacji z wieloma złożonymi problemami, wiedząc na razie tylko tyle, że stary parokrotnie zawiódł. Taka decyzja oparta być może tylko na wierze" (ibidem: 273-274). Kolejny problem, który stawia Kuhn, dotyczy rozwoju w nauce. Dlaczego w nauce miałby następować rozwój, z jakim nie mamy do czynienia na przykład w sztuce, teorii politycznej ani filozofii? „Termin 'nauka' zastrzeżony jest mianowicie w poważnej mierze do tych dziedzin, w których mamy do czynienia w sposób oczywisty z postępem. Najdobitniejszym tego przykładem mogą być współczesne dyskusje na temat, czy ta lub inna dziedzina nauk społecznych jest rzeczywiście nauką. Dyskusje te mają swoje odpowiedniki w przedparadygmatycznym okresie rozwoju tych dziedzin, które są dziś po- 
wszechnie do nauki zaliczane. [...] W historii, filozofii i w naukach społecznych literatura podręcznikowa ma już większe znaczenie. Ale nawet $w$ tych dyscyplinach elementarne wykłady uniwersyteckie wykorzystują równolegle źródła oryginalne, w tym prace 'klasyków' danej dziedziny oraz współczesne sprawozdania badawcze pisane dla specjalistów. W rezultacie student każdej z tych dyscyplin stale uświadamia sobie niezmierną różnorodność problemów, jakie na przestrzeni lat usiłowali rozwiązać przedstawiciele jego przyszłej grupy zawodowej. Co zaś jeszcze ważniejsze, ma on stale do czynienia z szeregiem konkurujących ze sobą i niewspółmiernych rozwiązań tych problemów, rozwiązań, które ostatecznie musi sam ocenić (ibidem: 285).

Thomas Kuhn uważa zatem, że paradygmaty są do pewnego stopnia niewspółmierne i nieporównywalne, ale odwołując się do istniejącej rzeczywistości możemy dokonać wyboru między nimi. Przedstawiciele nauk społecznych zapominają jednak często o ostrzeżeniu Kuhna, że jego schemat nie stosuje się do nauk społecznych. W konsekwencji w NSM, podobnie jak w innych naukach społecznych, przyjęto upraszczająca wersję tezy o niewspółmierności paradygmatów, implikująca, że każdy z nich wyjaśnia część rzeczywistości. Świat społeczny potraktowano jako obiekt, który może być widziany z różnych punktów obserwacyjnych, ale ciaggle pozostaje tym samym obiektem, różnice punktów widzenia zaś mogą być wyjaśnione przez różne teoretyczne założenia (Smith, 1999: 493). Powstaje jednak niepokojący problem: gdzie umieścić archimedesowy „punkt oparcia”, z którego uzyskamy najlepszy widok? Jak wybrać między rywalizującymi perspektywami tę ,najlepszą"? To pytanie pokazuje, że zastosowanie tez Kuhna na zasadzie analogii do nauk społecznych nie ma uzasadnienia. Jeśli teorie konstruują świat społeczny, nie istnieją uzasadnione podstawy wyboru między rywalizującymi paradygmatami, analogicznie do tez Kuhna sformułowanych w odniesieniu do świata naturalnego. $Z$ tego punktu widzenia każda interparadygmatyczna debata jest problematyczna. NSM oferuje zatem złudne przekonanie o możliwości wyboru paradygmatu, którego można użyć do najlepszego wyjaśnienia interesującego nas problemu.

Studenci, po kursie poświęconym TSM, nie mając możliwości jednoznacznego rozstrzygnięcia o prawomocności poszczególnych teorii, proponują często postępowanie polegające na wskazaniu określonej z nich jako nadającej się w szczególny sposób do wyjaśniania pewnych problemów. Na przykład: wojnę możemy najlepiej wyjaśnić, jeśli odwołamy się do realizmu politycznego; zachowania państw członków Unii Europejskiej - odwołując się do pluralizmu; stosunki zależności-odwołując się do globalistycznej, strukturalnej koncepcji systemów-światów. Tymczasem takie postępowanie pozwala dostrzec tylko różne części tego samego świata. Co pozostaje? Być może jedynie zgodzić się Maxem Weberem, który przekonywał, że wybór takiej czy innej teorii jest $\mathrm{w}$ istocie wyborem egzystencjalnym. To, jaką perspektywę wybieramy, jest jakby podsumowaniem naszego dotychczasowego życia i pozwala nam dowiedzieć się raczej czegoś o nas samych. W sposób nieunikniony u podstaw takiego wyboru leżą kwestie normatywne; wskazywał na to również Weber mówiąc, że jeśli nie wiesz, jaką wybrać teorię jako podstawę interpretacji świata i w konsekwencji działania, wybierz tę, dzięki której przyczynisz się do wzrostu sprawiedliwości na świecie. 


\section{Bibliografia}

Adler E. (1997), Seizing the Middle Ground: Constructivism in World Politics, „European Journal of International Relations", Vol. 3.

Banks M. (1984), The Evolution of International Relations Theory, in: Conflict in World Society, (ed.) M. Banks, Brighton.

Bierstaker T. J. (1989), Critical Reflections on Post-Positivism in International Relations, „International Studies Quarterly", Vol. 33, No. 3.

Brante Th. (2001), Consequences of Realism for Sociological Theory-Building, ,Journal for the Theory of Social Behaviour", Vol. 31, No. 2.

Buzan B., Jones C., Little R. (1993), The Logic of Anarchy: Neorealism to Structural Realism, New York.

Buzan B., Little R. (2001), Why International Relations Has Failed as an Intellectual Project and What to Do About It. Millennium, ,Journal of International Relations”, Vol. 30, No. 1.

Campbell D. (1996), Political Prosaics, Transversal Politics, and the Anarchical World, in: Challenging Boundaries: Global Flaws, Territorial Identities, (eds.) M. J. Schapiro, H. R. Alker, Minneapolis.

Campbell D. (2001), International Engagements: The Politics of North American International Relations Theory, „Political Theory”, Vol. 29, No. 3.

Chernoff F. (2002), Scientific Realism as a Meta-Theory of International Politics, „International Studies Quarterly", Vol. 46.

Crosby A. W. (1999), Imperializm ekologiczny. Biologiczna ekspansja Europy 900-1900, Warszawa.

Diamond J. (2000), Strzelby, zarazki, maszyny. Losy ludzkich społeczeństw, Warszawa.

Diamond J. (2007), Upadek. Dlaczego niektóre społeczeństwa upadty, a innym się udało, Warszawa.

Diez T., Steans J. (2005), A Useful Dialogue? Habermas and International Relations, „,Review of International Studies", Vol. 31, No. 1.

Dunne T. (1995), The Social Construction of International Society, „European Journal of International Relations", Vol. 1.

Elman C., Elman M. F. (2002), How Not to Be Lakatos Intolerant: Appraising Progress in IR Research, „International Studies Quarterly”, Vol. 46.

Fearon J. D., Wendt A. (2002), Rationalism versus Constructivism: A Skeptical View, in: Handbook of International Relations, (eds.) W. Carlsnaes, Th. Risse-Kappen, B. A. Simmons, Thousand Oaks.

Finnemore M., Sikkink K. (1998), International Norm Dynamics and Political Change, „International Organization", Vol. 52.

George J. (1994), Discourses of Global Politics: A Critical (Re)Introduction to International Relations, Boulder.

Gunnell J. G. (2009), Ideology and the philosophy of science: an American misunderstanding, „Journal of Political Ideologies", Vol. 14, No. 3.

Harvey F., Cobb J. (2003), Multiple Dialogues, Layered Syntheses, and the Limits of Expansive Cumulation, „International Studies Review”, Vol. 5.

Hellmann G. (2003), Are Dialogue and Synthesis Possible in International Relations?, „International Studies Review", Vol. 5.

Hellmann G. (2003), In Conclusion: Dialogue and Synthesis in Individual Scholarship and Collective Inquiry, „International Studies Review”, Vol. 5.

Idh-Shalom P. (2006), The Triptych of Realism, Elitism, and Conservatism, „International Studies Review", Vol. 8.

Jordan R. et al. (2009), One Discipline or Many? TRIP Survey of International Relations Faculty in Ten Countries, Teaching, Research, and International Policy (TRIP) Project, Virginia. 
Katzenstein P. J., Keohane R. O., Krasner S. D. (1998), International Organization and the Study of World Politics, „International Organization”, Vol. 52.

Keohane R. O. (1988), International Institutions: Two Approaches, „International Studies Quarterly”, Vol. 32, No. 4.

Keohane R. O. (1989), International Institutions and State Power: Essays in International Relations Theory, Boulder.

Keohane R. O., Nye J. S. (1989), Power and Interdependence, New York.

Krasner S. (2000), Wars, Hotel Fires, and Plane Crashes, „Review of International Studies”, Vol. 26.

Kratochwil F. (2003), The Monologue of ,, Science”, „International Studies Review”, Vol. 5.

Kreisler H. (2003), Theory and International Politics: Conversation with Kenneth N. Waltz, 10 February 2003, http://globetrotter.berkeley.edu/people3/Waltz/ (26.05.2011).

Kuhn T. S. (1985), Dwa bieguny. Tradycja i nowatorstwo w badaniach naukowych, Warszawa.

Kuhn T. S. (2001), Struktura rewolucji naukowych, Warszawa.

Kuhn T. S. (2003), Droga po strukturze, Warszawa.

Kurki M., Wight C. (2007), International Relations and Social Science, in: International Relations Theories: Discipline and Diversity, (eds.) T. Dunne, M. Kurki, S. Smith, Oxford.

Kurki M. (2009), The politics of the philosophy of science, „International Theory”, Vol. 1, No. 3.

Lapid Y. (1989), The Third Debate: On the Prospects of International Theory in a Post-Positivist Era, „International Studies Quarterly”, Vol. 33, No. 3.

Lee W-Y. (2007), A Pragmatic Case against Pragmatic Scientific Realism, „,ournal for General Philosophy of Science", Vol. 38.

Legro J. W., Moravcsik A. (1999), Is Anybody Still a Realist?, „International Security”, Vol. 24, No. 2.

Liebrucks A. (2001), The Concept of Social Construction, „Theory \& Psychology”, Vol. 11, No. 3.

Linklater A. (1996), The Achievments of Critical Theory, in: International Theory: Positivism and Beyond, (eds.) S. Smith, K. Booth, M. Zalewski, Cambridge.

Lyons T. D. (2009), Non-competitor Conditions in the Scientific Realism Debate, „International Studies in the Philosophy of Science", Vol. 23, No. 1.

Mansbach R. W., Vasquez J. A. (1981), In Search of Theory. A New Paradigm for Global Politics, New York.

Mansbach R. W., Vasquez J. A. (1990), Between Celebration and Despair: Constructive Suggestions for Future International Theory, Annual ISA Meeting, Washington.

March J. G., Olsen J. P. (1998), The Institutional Dynamics of International Political Orders, „International Organization", Vol. 52.

McPhee W. N. (1963), Formal Theories of Mass Behavior, New York.

Monteiro N. P., Ruby K. G. (2009), IR and the false promise of philosophical foundations, „International Theory", Vol. 1, No. 1.

Moore J. (2010), Philosophy of Science, with Special Consideration Given to Behaviorism as the Philosophy of the Science of Behavior, „The Psychological Record”, Vol. 60.

Moravcsik A. (1997), A Liberal Theory of International Politics, „International Organization”, Vol. 51.

Morawcsik A. (2003), Theory Synthesis in International Relations: Real Not Metaphysical, „International Studies Review", Vol. 5.

Patomäki H. (2002), From East to West: Emergent Global Philosophies - Beginnings of the End of Western Dominance?, „Theory, Culture \& Society”, Vol. 19, No. 3.

Patomäki H., Wight C. (2000), After Postpositivism? The Promises of Critical Realism, „International Studies Quarterly", Vol. 44, No. 2. 
Pleasants N. (2003), A Philosophy for the Social Sciences: Realism, Pragmatism, or Neither?, „Foundations of Science", Vol. 8.

Pond E., Waltz K. N. (1994), Correspondence: International Politics, Viewed from the Ground, „International Security", Vol. 19, No. 1.

Preston J. M. (2003), Kuhn, instrumentalism, and the progress of science, „Social Epistemology”, Vol. 17 , No. 2-3.

Price R., Reus-Smit Ch. (1998), Dangerous Liaisons?: Critical International Theory and Constructivism, „European Journal of International Relations”, Vol. 4, No. 3.

Progress in International Relations. Appraising the Feld (2003), (eds.) C. Elman, M. F. Elman, Cambridge.

Rouse J. (2002), Vampires: Social Construction, Realism, and Other Philosophical Undead, „History and Theory", Vol. 41.

Ruggie J. (1998), Constructing the World Polity: Essays on International Institutionalization, London.

Russett B. M., O’Neal J. R. (2001), Triangulating Peace: Democracy, Interdependence, and International Organization, New York.

Schmidt B. (2007), International Relations Theory: Hegemony or Pluralism?, „Millennium: Journal of International Studies", Vol. 36, No. 2.

Smith S. (1992), The Forty Years' Detour: The Resurgence of Normative Theory in International Relations, „Millennium: Journal of International Studies”, Vol. 21, No. 3.

Smith S. (1995), The Self-Images of a Discipline: A Genealogy of International Relations Theory, in: International Relations Theory Today, (eds.) K. Booth, S. Smith, Cambridge.

Smith S. (2000), The discipline of international relations: still an American social science?, „British Journal of Politics and International Relations", Vol. 2, No. 3.

Smith S. (2003), Dialogue and the Reinforcement of Orthodoxy in International Relations, ,International Studies Review", Vol. 5.

Snyder J. (1991), Myths of Empire: Domestic Politics and International Ambition, Ithaca.

Sørensen G. (1991), A Revised Paradigm for International Relations: The „Old” Images and the Postmodernist Challenge, „Cooperation and Conflict”, Vol. 26, No. 85.

Thies C. G. (2004), Are Two Theories Better Than One? A Constructivist Model of the Neorealist-Neoliberal Debate, „International Political Science Review”, Vol. 25, No. 2.

Van Evera S. (1990/1991), Primed for Peace: Europe after the Cold War, „International Security”, Vol. 61, No. 3.

Vasquez J. A. (1998), The Power of Power Politics. From Classical Realism to Neotraditionalism, Cambridge.

Wæver O. (1996), The Rise and Fall of the Interparadigm Debate, in: International Theory: Positivism and Beyond, (eds.) S. Smith, K. Booth, M. Zalewski, Cambridge.

Wæver O. (1997), Figures of International Thought: Introducing Persons instead of Paradigms, in: The Future of International Relations: Masters in the Making, (eds.) I. B. Neumann, O. Wæver, London.

Wæver O. (2009), Waltz's Theory of Theory, „International Relations”, Vol. 23, No. 2.

Walt S. (1987), The Origins of Alliances, Ithaca.

Walt S. (1998), International relations: one world, many theories, „Foreign Policy”, Vol. 110.

Waltz K. N. (1979), Theory of International Politics, Reading: Addison-Wesley.

Waltz K. N. (2000), Structural Realism after the Cold War, „International Organization”, Vol. 25, No. 1.

Waltz K. N. (2010), Struktura teorii stosunków międzynarodowych, Warszawa. 
Wendt A. (1995), Constructing International Politics, „International Security”, Vol. 20, No. 1. Wendt A. (2008), Społeczna teoria stosunków międzynarodowych, Warszawa.

\title{
STRESZCZENIE
}

Nauka o stosunkach międzynarodowych nie jest pewna swojego statusu jako „nauka” i racjonalne przedsięwzięcie zdolne do wytwarzania wiedzy o świecie polityki międzynarodowej. W długiej dyscyplinarnej historii legitymizacji pola badawczego jako „naukowego” badacze stosunków międzynarodowych importowali wiele stanowisk z filozofii nauki w celu ustanowienia pewnych fundamentów nauki o stosunkach międzynarodowych. Kwestie filozoficzne są zazwyczaj traktowane jako uniwersalne, ponadczasowe i abstrakcyjne w swojej naturze. Filozofia nauki zajmuje się badaniem abstrakcyjnych kwestii logicznych, epistemologicznych i ontologicznych związanych w szczególności z problemem w jaki sposób sądy naukowe są uzasadniane lub strukturyzowane. Niestety, żadne takie pewne fundamenty nie istnieją. Filozofia nauki sama stanowi kontestowane pole badań, w którym nie istnieje konsensus odnośnie właściwych fundamentów nauki. Na jej gruncie ustanowiono co najmniej trzy dobrze uzasadnione stanowiska fundacyjne: instrumentalizm, społeczny konstruktywizm i naukowy realizm. Żadne z nich nie uzyskało powszechnej akceptacji. Artykuł przedstawia napięcia między różnymi filozofiami nauki. Debaty nad ,nauką” w stosunkach międzynarodowych podzieliły dyscyplinę w kwestii możliwości ustanowienia naukowych stosunków międzynarodowych. Stanowiska fundacyjne stały się istotnym elementem w sposobie myślenia badaczy stosunków międzynarodowych o swojej pracy naukowej. Podziały między pozytywistami, antypozytywistami i postpozytywistami stały się nieuniknionym rezultatem roszczeń poszczególnych grup badaczy do zajmowania słusznego stanowiska w filozofii nauki.

\section{INTERNATIONAL RELATIONS THEORY AND PHILOSOPHY OF SCIENCE}

\begin{abstract}
International Relations is uncertain about its status as a „science” and as a rational enterprise capable of producing knowledge about the world of international politics. Throughout a long disciplinary history of attempts to legitimate the field as ,scientific”, International Relations scholars have imported many positions from Philosophy of Science in order to ground International Relations on an unshakable foundation. Philosophical questions are commonly seen as universal, timeless, and abstract in nature. As for Philosophy of Science, it is conceived to involve the study of abstract questions of logic, epistemology, and ontology, specifically in relations to how scientific claims are justified or structured. Alas, no such unshakable foundation exists. The Philosophy of Science is itself a contested field of study, in which no consensus exists on the proper foundation for science. There are at least three well-supported foundational positions: Instrumentalism, Social Constructivism and Scientific Realism. None of them has produced consensus among philosophers. In this article, author presents tensions between different Philosophy of Science and International Relations Theory. The „science” debates in International Relations has divided the discipline on the possibility of a science international relations. Foundational positions have become part and parcel of the way International Relations scholars think about their scientific work. The ongoing division among positivists, anti-positivists, and post-positivists is the inevitable result of each side's claim to represent the right position in the Philosophy of Science.
\end{abstract}

